\title{
Effects of Projected Changes in Wind, Atmospheric Temperature, and Freshwater Inflow on the Ross Sea ${ }^{\mathfrak{O}}$
}

\author{
Michael S. Dinniman, John M. Klinck, and Eileen E. Hofmann \\ Center for Coastal Physical Oceanography, Old Dominion University, Norfolk, Virginia \\ WALKER O. SMITH JR. \\ Virginia Institute of Marine Science, College of William and Mary, Gloucester Point, Virginia
}

(Manuscript received 30 May 2017, in final form 15 November 2017)

\begin{abstract}
A 5-km horizontal resolution regional ocean-sea ice-ice shelf model of the Ross Sea is used to examine the effects of changes in wind strength, air temperature, and increased meltwater input on the formation of highsalinity shelf water (HSSW), on-shelf transport and vertical mixing of Circumpolar Deep Water (CDW) and its transformation into modified CDW (MCDW), and basal melt of the Ross Ice Shelf (RIS). A 20\% increase in wind speed, with no other atmospheric changes, reduced summer sea ice minimum area by $20 \%$, opposite the observed trend of the past three decades. Increased winds with spatially uniform, reduced atmospheric temperatures increased summer sea ice concentrations, on-shelf transport of CDW, vertical mixing of MCDW, HSSW volume, and (albeit small) RIS basal melt. Winds and atmospheric temperatures from the SRES A1B scenario forcing of the MPI ECHAM5 model decreased on-shelf transport of CDW and vertical mixing of MCDW for 2046-61 and 2085-2100 relative to the end of the twentieth century. The RIS basal melt increased slightly by $2046-61$ (9\%) and 2085-2100 (13\%). Advection of lower-salinity water onto the continental shelf did not significantly affect sea ice extent for the 2046-61 or 2085-2100 simulations. However, freshening reduces on-shelf transport of CDW, vertical mixing of MCDW, and the volume of HSSW produced. The reduced vertical mixing of MCDW, while partially balanced by the reduced on-shelf transport of CDW, enhances the RIS basal melt rate relative to the twentieth-century simulation for 2046-61 (13\%) and 2085-2100 (17\%).
\end{abstract}

\section{Introduction}

The Ross Sea continental shelf and slope (Fig. 1) is one of the few locations where Antarctic Bottom Water (AABW) is formed and exported to the World Ocean (Orsi et al. 1999; Gordon et al. 2009; Budillon et al. 2011), and thus, processes that alter the formation of this water mass affect the global thermohaline circulation (Jacobs 2004; Lumpkin and Speer 2007; Marshall and Speer 2012). Transport of relatively warm $\left(>1^{\circ} \mathrm{C}\right)$, saline $(\sim 34.6)$ Circumpolar Deep Water $(\mathrm{CDW})$ and cold (often $\left.<-1.5^{\circ} \mathrm{C}\right)$ and fresh $(<34.3)$ Antarctic Surface

\footnotetext{
Supplemental information related to this paper is available at the Journals Online website: https://doi.org/10.1175/JCLI-D-170351.s1.

Corresponding author: Michael S. Dinniman, msd@ccpo.odu. edu
}

Water (AASW) onto the Ross Sea continental shelf is important to the formation of shelf water (SW; a precursor to AABW) and AABW (Orsi et al. 2002; Gordon et al. 2009; Orsi and Wiederwohl 2009). The input of CDW also modifies the basal melt of the Ross Ice Shelf (RIS; Jacobs et al. 1979, 1985; Smethie and Jacobs 2005). Thus, changes in the off-shelf transport of AABW or onshelf transport of CDW or AASW can have implications well beyond the local environs of the Ross Sea.

The CDW along the continental shelf break of the Ross Sea separates from the Antarctic Circumpolar Current, which is well north of the shelf break in this sector, and flows to the west as the southern limb of the Ross Gyre (Orsi and Whitworth 2005; Orsi and Wiederwohl 2009). On-shelf intrusions of this water mass occur primarily along the eastward side of northsouth troughs that cross the continental shelf (Orsi and Wiederwohl 2009; Kohut et al. 2013). Once on the shelf, vertical mixing modifies CDW to produce a cooler and 


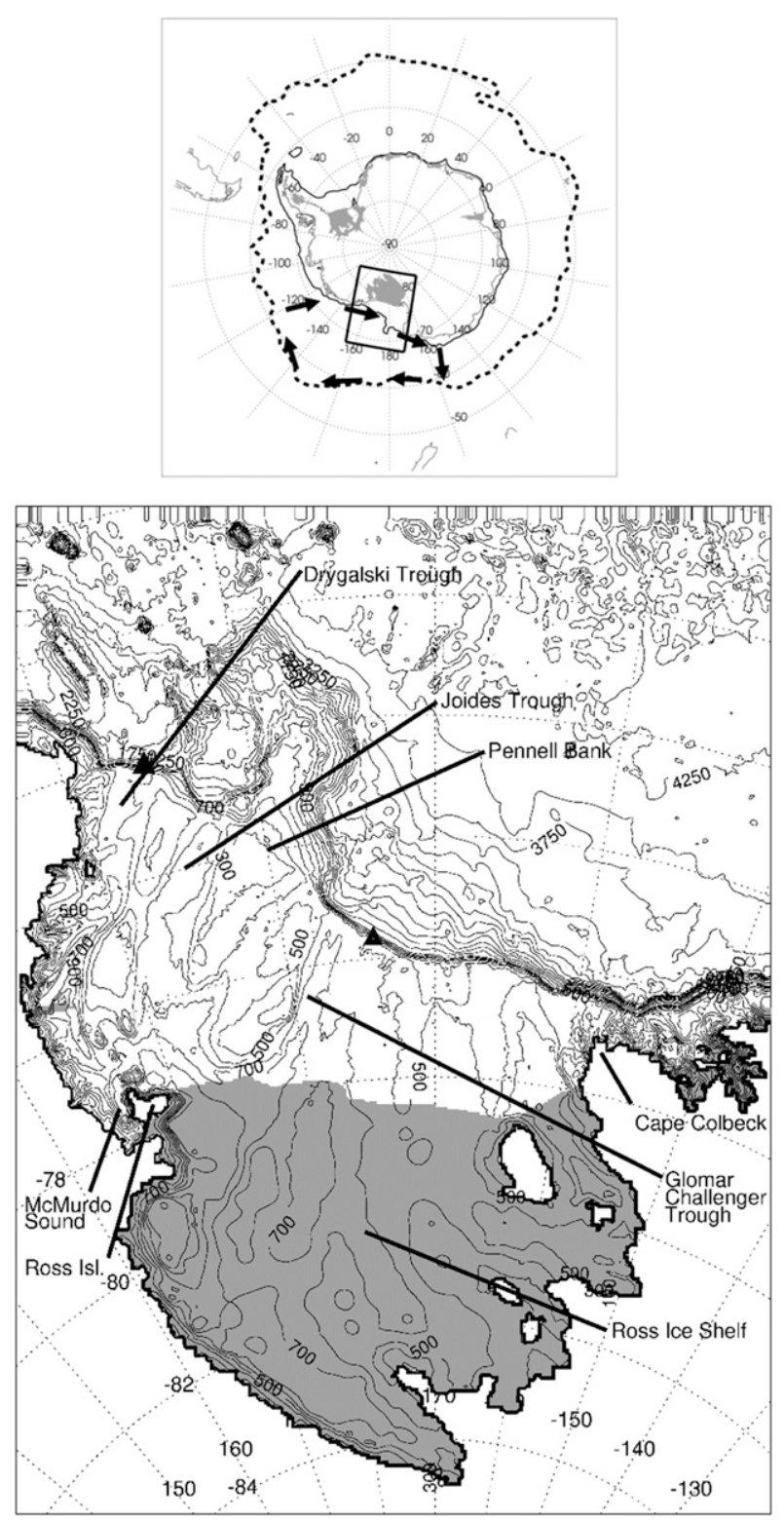

FIG. 1. (top) Southern Ocean showing the Polar Front (dashed line, approximate position of Antarctic Circumpolar Current), Ross Gyre (arrows), shelf break (thin black line, 1000-m contour), floating ice shelves (shaded areas), and Ross Sea model domain (black box). (bottom) Domain for the Ross Sea model showing bathymetry (100-m contours to $1000-\mathrm{m}$ depth and $250-\mathrm{m}$ contours deeper than $1000 \mathrm{~m}$ ) and ice shelves (shaded areas). The two locations used for examining shelf break current (see Table 5) are noted by triangles.

saltier form, modified CDW (MCDW; Jacobs and Giulivi 1999; Gordon et al. 2000; Orsi and Wiederwohl 2009). Sea ice formation converts the waters advected onto the shelf (MCDW and AASW) into SW, which is apportioned into high-salinity shelf water (HSSW) on the western part of the shelf $(S>34.62$; Orsi and
Wiederwohl 2009) and low-salinity shelf water (LSSW). The mixture of meltwater from the base of the floating RIS with other shelf waters forms ice shelf water (ISW), which is identifiable by temperatures below the surface freezing point $\left(<-1.95^{\circ} \mathrm{C}\right)$.

A portion of the AASW (Whitworth et al. 1998) enters the eastern Ross Sea near Cape Colbeck (Fig. 1) as a narrow coastal current. This flow transports fresher surface waters from the Amundsen Sea, which may be changing salinity as a result of increased basal melt of ice shelves in the Amundsen Sea (Jacobs et al. 2002; Jacobs and Giulivi 2010; Nakayama et al. 2014). The observed freshening of $0.03 \mathrm{decade}^{-1}$ over the southwestern continental shelf of the Ross Sea over the last 50 years is thought to result from this input (Jacobs et al. 2002; Jacobs and Giulivi 2010; Budillon et al. 2011; Comiso et al. 2011; Nakayama et al. 2014; Schmidtko et al. 2014). Continued input of lower-salinity water will alter shelf water stratification, potentially changing the properties of bottom and deep waters formed in this region (Aoki et al. 2005; Rintoul 2007; Jacobs and Giulivi 2010; Shimada et al. 2012; Purkey and Johnson 2013).

Water mass formation processes in the Ross Sea are modulated by sea ice extent, duration, and the presence of polynyas. Sea ice extent in the Ross Sea sector of the Southern Ocean (including the continental shelf and the abyssal ocean out beyond the Ross Gyre) has increased during the past 35 years $\left(\sim 5 \%\right.$ decade $^{-1}$; Comiso et al. 2011). Over the Ross Sea continental shelf, the duration of the summer ice-free period has decreased (Parkinson 2002; Stammerjohn et al. 2008, 2012), ice production of the Ross Sea polynya has increased (Comiso et al. 2011), and sea surface temperature has decreased (Comiso 2010; Comiso et al. 2017). These changes have been attributed to increased strength of the cold southerly winds that extend over the RIS and the continental shelf (Turner et al. 2009; Holland and Kwok 2012; Turner et al. 2016), which in turn have been linked to changes in the ozone hole over Antarctica (Turner et al. 2009) and deepening of the Amundsen Sea low in response to variability in the tropical Pacific Ocean (Ding et al. 2011) and the north and tropical Atlantic Ocean ( $\mathrm{Li}$ et al. 2014).

In contrast with the recent trends, air temperatures over the Ross Sea are predicted to increase in the next century (approximately $3^{\circ} \mathrm{C}$ by 2100 ; Bracegirdle and Stephenson 2012). Coupled with projected changes in wind strength, this may lead to decreased local sea ice extent, reduced sea ice season, and longer periods of icefree conditions in the Ross Sea (Smith et al. 2014). Continued freshening of the Ross Sea via remote inputs will also alter upper-ocean stratification and vertical mixing. These changes in forcing and local hydrographic 
structure will potentially alter the circulation and water formation processes in the Ross Sea, but the extent to which this will happen is unknown.

The objective of this study is to investigate the changes in ocean circulation that are occurring in response to strengthening winds over the Ross Sea and the sensitivity of the circulation to projected winds, atmospheric temperatures, and freshwater inflow. This is addressed using a 5-km horizontal resolution coupled ocean-sea ice-ice shelf model of the Ross Sea (Dinniman et al. 2007, 2011; Stern et al. 2013; Mack et al. 2017) that is forced by prescribed changes to present wind and atmospheric temperature fields and by projected winds and air temperatures from one IPCC Fourth Assessment Report (AR4) climate model. Analyses of the simulation output quantify the effects of modified forcing on the Ross Sea circulation, water masses, and the RIS basal melt.

\section{Circulation model and experiments}

\section{a. Model structure}

The Ross Sea circulation model is an implementation of the Regional Ocean Modeling System (ROMS), which is a primitive-equation, finite-difference model with a terrain-following vertical coordinate system (Haidvogel et al. 2008; Shchepetkin and McWilliams 2009). The model domain extends southward to include most of the cavity underneath the RIS and northward past the shelf break to $67.5^{\circ} \mathrm{S}$ (Fig. 1). The model uses 5-km horizontal grid spacing and 24 vertical layers with variable thicknesses that depend on water column depth and are smaller at the surface and bottom. The model topography [from the International Bathymetric Chart of the Southern Ocean (IBCSO; Arndt et al. 2013) and Bedmap2 (Fretwell et al. 2013); details in Mack et al. (2017)] includes the elevation of the bedrock and the base of any floating ice shelves (primarily the RIS).

Sea ice is simulated with a dynamic sea ice model (Budgell 2005) that is based on two-layer ice thermodynamics (and a molecular sublayer beneath the sea ice) described by Mellor and Kantha (1989) and Häkkinen and Mellor (1992). A snow layer is included, as well as a conversion of snow to ice when the snow-ice interface is below sea level, along with a simple estimate of frazil ice production (Steele et al. 1989). Ice dynamics are based on an elastic-viscous-plastic rheology (Hunke and Dukowicz 1997; Hunke 2001). The ice model has one thickness category, which is adequate because of the limited multiyear ice in the Antarctic (Comiso 2010). This sea ice model has been shown to accurately simulate sea ice concentrations in the Ross Sea (Stern et al. 2013) and
TABLE 1. Summary of prescribed forcing simulations. The current winds and atmospheric temperatures are the ERA-Interim values for 1999-2014. Modifications to the current wind fields consisted of scaling each wind component by a constant factor that decreased the wind strength by $20 \%(0.8)$ or increased it by $20 \%$ (1.2). Modifications to the current atmospheric temperatures consisted of reducing the forcing temperature at every grid point for every time step by $1.0^{\circ} \mathrm{C}$.

\begin{tabular}{llc}
\hline \hline Simulation & Wind strength & Atmospheric temperature \\
\hline Base & Current & Current \\
Wind*0.8 & Current $\times 0.8$ & Current \\
Wind*1.2 & Current $\times 1.2$ & Current \\
T $-1.0 \mathrm{C}$ & Current & Current $-1.0^{\circ} \mathrm{C}$ \\
$\mathrm{T}-1.0 \mathrm{C}+$ & Current $\times 1.2$ & Current $-1.0^{\circ} \mathrm{C}$ \\
\hline
\end{tabular}

in other regional implementations around Antarctica (Dinniman et al. 2011, 2015).

The model ice shelves are static; thinning (or thickening) of the ice shelf and iceberg calving are not included. The mechanical and thermodynamic interactions between the floating RIS and the water cavity underneath (Holland and Jenkins 1999; Dinniman et al. 2011) are included as model processes. Open ocean momentum, heat, and freshwater (imposed as a salt flux) fluxes are calculated from the COARE version 3.0 (COARE 3.0) bulk flux algorithm (Fairall et al. 2003), and there is no relaxation of surface temperature or salinity to a specified field. Vertical momentum and tracer mixing were computed using the K-profile parameterization (KPP; Large et al. 1994) but modified such that the surface boundary layer depth under stabilizing conditions with nonzero surface shortwave flux is set to a minimum depth, equal to the directly wind-forced minimum depth under stable conditions in a Kraus-Turner bulk mixed layer model (Niiler and Kraus 1977; Dinniman et al. 2012). Ocean tides are not included in these simulations.

\section{b. Simulations}

All simulations used in this study start from the end of the same 6-yr model initialization and spinup simulation (Dinniman et al. 2011). Lateral boundary conditions for ice concentration are from monthly data for 1999-2014 from passive microwave satellite observations (SSM/I) and are applied as a fixed value at any boundary point where the computed ice velocity is into the model domain. Monthly climatologies of temperature and salinity from the World Ocean Atlas 2001 (WOA01) and barotropic velocities from the Ocean Circulation and Climate Advanced Modelling project (OCCAM; Saunders et al. 1999) are also used on the lateral open boundaries.

Two sets of simulations were performed. For the first set (Table 1), a base simulation was obtained using 6-hourly winds and air temperatures and monthly humidity and 
TABLE 2. Summary of the wind and atmospheric temperature forcing fields and imposed boundary freshening used for the climate model forced simulations.

\begin{tabular}{|c|c|c|c|}
\hline Simulation & Winds & Atmospheric temperature & Boundary freshening \\
\hline $\begin{array}{l}\text { Twentieth } \\
\text { century }\end{array}$ & $\begin{array}{l}\text { Daily ECHAM5 twentieth-century } \\
\text { run (Sep 1985-Sep 2000). }\end{array}$ & ERA-Interim monthly climatology (1985-2000). & No \\
\hline 2050 & $\begin{array}{l}\text { Daily ECHAM5 A1B scenario } \\
\text { (Sep 2046-Sep 2061). }\end{array}$ & $\begin{array}{l}\text { ECHAM5 A1B (Sep 2046-Sep 2061) anomaly relative } \\
\text { to twentieth century plus ERA-Interim climatology. }\end{array}$ & No \\
\hline $2050 \mathrm{~F}$ & $\begin{array}{l}\text { Daily ECHAM5 A1B scenario } \\
\quad \text { (Sep 2046-Sep 2061). }\end{array}$ & $\begin{array}{l}\text { ECHAM5 A1B (Sep 2046-Sep 2061) anomaly relative } \\
\text { to twentieth century plus ERA-Interim climatology. }\end{array}$ & Yes \\
\hline 2100 & $\begin{array}{l}\text { Daily ECHAM5 A1B scenario } \\
\text { (Sep 2085-Sep 2100). }\end{array}$ & $\begin{array}{l}\text { ECHAM5 A1B (Sep 2085-Sep 2100) anomaly relative } \\
\text { to twentieth century plus ERA-Interim climatology. }\end{array}$ & No \\
\hline $2100 \mathrm{~F}$ & $\begin{array}{l}\text { Daily ECHAM5 A1B scenario } \\
\text { (Sep 2085-Sep 2100). }\end{array}$ & $\begin{array}{l}\text { ECHAM5 A1B (Sep 2085-Sep 2100) anomaly relative } \\
\text { to twentieth century plus ERA-Interim climatology. }\end{array}$ & Yes \\
\hline
\end{tabular}

sea level pressure from ERA-Interim (Dee et al. 2011). Computed coastal precipitation around Antarctica is affected by atmospheric model resolution (e.g., van Lipzig et al. 2004). Therefore, a monthly climatology of precipitation derived from forecasts from the Antarctic Mesoscale Prediction System (AMPS; Powers et al. 2003; Bromwich et al. 2005), which uses a mesoscale meteorological model to compute high-resolution atmospheric forecast fields for operational use in Antarctica, was used instead of the ERA-Interim precipitation. ERA-Interim also overestimates mean clouds over the Southern Ocean south of $60^{\circ} \mathrm{S}$ (Naud et al. 2014), so a monthly cloud fraction climatology from the International Satellite Cloud Climatology Project stage D2 (ISCCP D2; Rossow et al. 1996) was used. The base simulation (Base; Table 1) was run for 15 years, starting from the end of the 6-yr spinup simulation, with forcing from 15 September 1999 to 15 September 2014.

Other simulations were forced with modified wind and/or air temperature distributions (Table 1) and run for 15 years. Changes to the wind fields were imposed by scaling each component of the ERA-Interim winds (Fig. S1 in the supplemental material) by a constant factor, either 0.8 (Wind* 0.8 ; Table 1 ) or 1.2 (Wind*1.2; Table 1 ), to provide a $20 \%$ decrease and increase in wind speed, respectively. The upper limit approximates the change expected if the currently observed mean increase in winds over the Ross Sea $[\sim 1.5 \%-$ $2.5 \%$ decade $^{-1}$; Fig. 1 in Zhang (2014)] continued for a century. Air temperature was modified by uniformly decreasing the atmospheric temperature by $1^{\circ} \mathrm{C}$ over the entire model domain ( $\mathrm{T}-1.0 \mathrm{C}$; Table 1$)$, which is meant to represent an observed cooling over the coastal Ross Sea [e.g., Fig. 7 in Comiso et al. (2017)]. The final simulation $(\mathrm{T}-1.0 \mathrm{C}+$; Table 1$)$ included the combined effects of increased winds (multiplied by 1.2) and decreased atmospheric temperatures $\left(-1.0^{\circ} \mathrm{C}\right)$, which represents enhanced cold southerlies over the Ross Sea.
A second set of simulations (Table 2) compared the effects of current and projected wind and air temperature distributions. Some of these simulations are similar to shorter simulations described in Smith et al. (2014). The current conditions simulation (Twentieth century; Table 2) used daily winds for September 1985 through September 2000 obtained from the MPI ECHAM5 climate model (Jungclaus et al. 2006) twentieth-century experiment, which is one of the best-performing AR4 climate models in the Antarctic (Connolley and Bracegirdle 2007). A comparison of the twentieth-century ECHAM5 wind fields with the ERA-Interim winds over the Ross Sea showed that the mean structure of the winds was similar, except for the ERA-Interim winds generally being stronger near the coast and RIS Front.

As described in Smith et al. (2014), the twentiethcentury daily air temperatures from ECHAM5 are often much colder than reanalysis temperatures over the Ross Sea (summer climatology differences of up to $8^{\circ} \mathrm{C}$ ), especially near the coast and RIS Front. Simulations using the ECHAM5 twentieth-century temperatures did not produce a significant summer expansion of the Ross Sea polynya. Therefore, a monthly climatology constructed from the ERA-Interim air temperatures over the 15-yr simulation was used as forcing for the twentieth-century simulation (details in Smith et al. 2014). The other forcing fields were the same as those in the first set of simulations.

The projected forcing simulations were run for two 15 -yr periods that correspond to the middle (September 2046-September 2061) and end (September 2085September 2100) of the twenty-first century using daily winds from phase 3 of the Coupled Model Intercomparison Project (CMIP3) A1B emissions scenario of the ECHAM5 model. Monthly climatologies of the difference between the ECHAM5 A1B and the ECHAM5 twentieth-century air temperatures were computed and added to the ERA-Interim climatology to create forcing fields for the projected forcing simulations. The adjusted air temperatures were $2.01^{\circ} \pm 1.47^{\circ} \mathrm{C}$ warmer 
for 2046-61 (2050 and 2050F simulations; Table 2) and $3.42^{\circ} \pm 2.09^{\circ} \mathrm{C}$ warmer for $2085-2100$ (2100 and $2100 \mathrm{~F}$ simulations) relative to the twentieth-century air temperatures over the Ross Sea model domain.

Observations (Jacobs and Giulivi 2010; Comiso et al. 2011) and models (Nakayama et al. 2014) suggest that much of the Ross Sea freshening originates in the Amundsen-Bellingshausen Sea and is transported into the eastern Ross Sea. In previous simulations (Smith et al. 2014), this observed freshening was simulated by uniformly reducing the salinity along all lateral model boundaries by 0.12 throughout the water column. However, here $(2050 \mathrm{~F}$ and $2100 \mathrm{~F}$; Table 2), we increase the salinity reduction at the open boundaries to 0.20 (still throughout the entire water column), but it is applied only at the eastern and western boundaries over the continental shelf and slope (linearly decreased to zero between 1000and 3000-m depth). Using the boundary condition velocities on the eastern boundary (which generally flow into the model domain) results in an approximate increased freshwater flux of $347 \mathrm{Gt} \mathrm{yr}^{-1}$. The mean salinity over the continental shelf adjusts to the new boundary values in $3-4 \mathrm{yr}$ (not shown), and the mean freshening of the shelf waters $(\sim 0.11-0.12)$ approximately matches the observed level of freshening of the Ross Sea $\left(-0.03\right.$ decade $^{-1}$ near Ross Island, -0.04 decade $^{-1}$ in MCDW near the RIS, and -0.08 decade $^{-1}$ above $200 \mathrm{~m}$ along the RIS and near the slope front; Jacobs and Giulivi 2010).

A dye tracer (initial concentration of 100 arbitrary dimensionless units) is placed off the continental shelf (defined by the $800-\mathrm{m}$ isobath) at the end of the 6-yr model spinup at any depth with temperature greater than $0.0^{\circ} \mathrm{C}$ (indicator of $\mathrm{CDW}$ ) and used to track the transport of CDW [see Fig. 7 in Dinniman et al. (2011)]. Once a simulation is initiated, the dye tracer advects and diffuses, providing the temporal evolution of the input and distribution of CDW on the Ross Sea continental shelf. The off-shelf dye source at the open boundaries provides a continuous source to the model domain. There are no surface or bottom fluxes of dye, and there are no sinks of dye other than advection out of the model domain at the open boundaries. To show differences in the transient spinup response to different forcings, as well as the steady-state differences, all the averages are computed from the entire $15 \mathrm{yr}$ of each model run.

\section{Effects of prescribed atmospheric changes}

\section{a. Effect on sea ice}

In the base simulation, the entire Ross Sea continental shelf $\left(0.43 \times 10^{6} \mathrm{~km}^{2}\right)$ is almost fully covered by sea ice for most of the year (Fig. 2), with the decrease in ice area
Ice Area
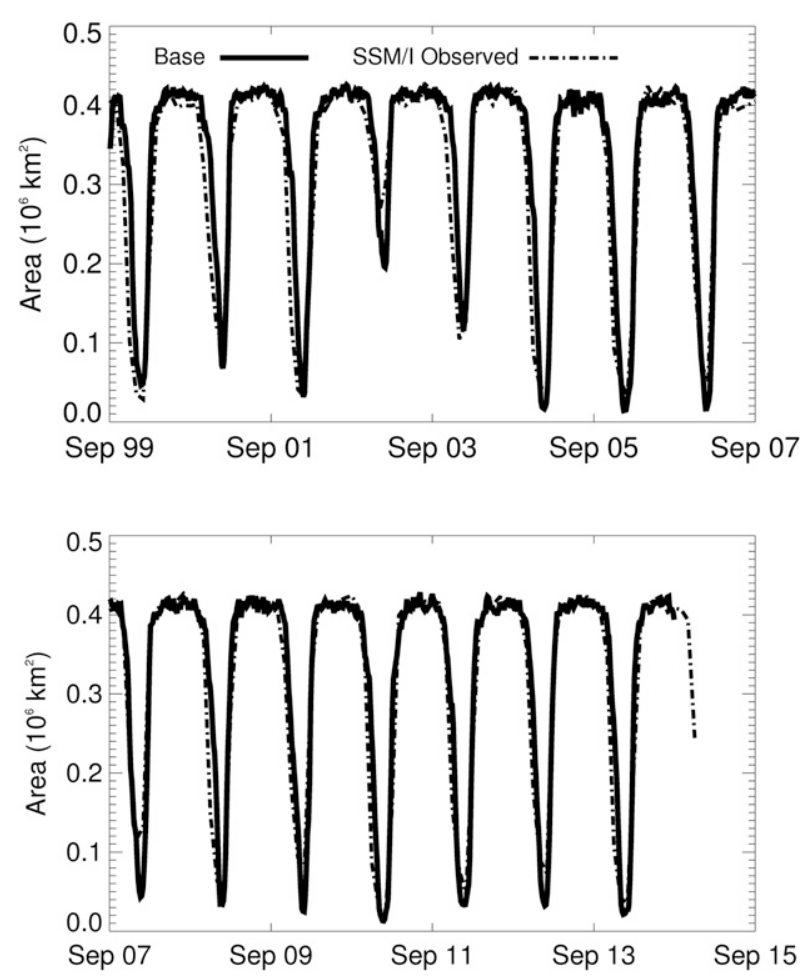

FIG. 2. Monthly simulated and observed SSM/I (dashed-dotted line) sea ice area $\left(10^{6} \mathrm{~km}^{2}\right)$ calculated for the continental shelf for the Base case 1999-2014 simulation. Note that the area of the entire open continental shelf is $0.43 \times 10^{6} \mathrm{~km}^{2}$.

in the austral summer representing the expansion of the Ross Sea polynya. The simulated sea ice area matches observed sea ice area derived from Special Sensor Microwave Imager (SSM/I) observations (Fig. 2). In some years, expansion of the simulated Ross Sea polynya is late relative to observations, but the summer minimum and fall ice advance match observations, capturing the primary seasonal response $[r=0.953$; skill score $=0.970$ (Willmott 1981)]. The interannual variations in the summer polynya extent also match observations (Fig. 2) as indicated by comparison of the interannual anomalies (computed by removing the average seasonal cycle) of the simulated and observed sea ice distributions $(r=0.771$; skill score $=0.860)$.

The Ross Sea continental shelf is a net producer of sea ice, with much of the ice created in coastal polynyas (primarily the Ross Sea polynya; Fig. 3) during winter. Some of the newly formed sea ice is melted in situ during summer, but more export than import of ice occurs over the course of the year (Kwok 2005; Martin et al. 2007; Comiso et al. 2011). The total volume flux over the continental shelf between the ocean and the ice (i.e., ice 

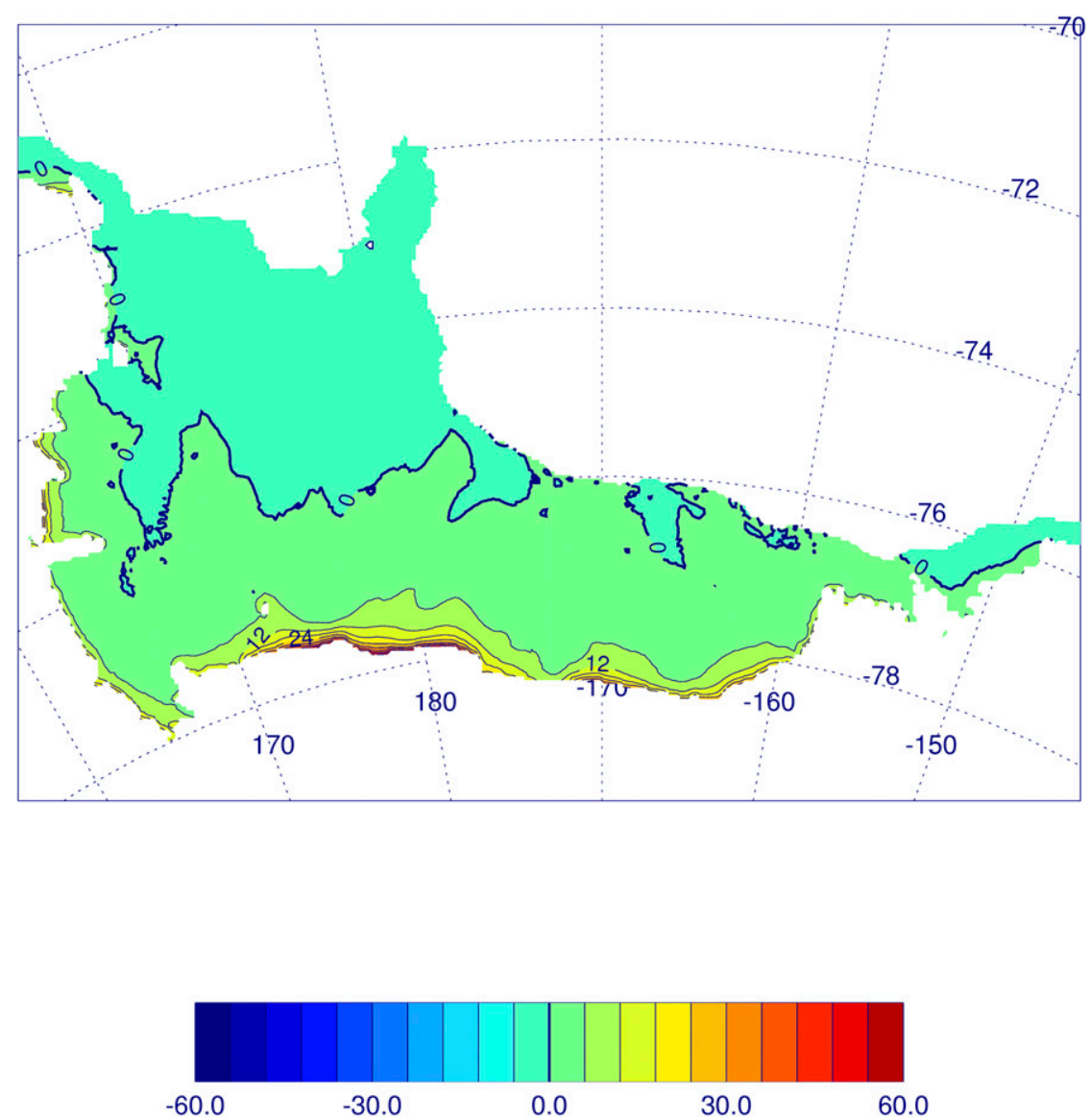

FIG. 3. Distribution of the simulated net annual sea ice production $\left(\mathrm{m} \mathrm{yr}^{-1}\right)$ over the model continental shelf for the Base case simulation.

created/removed by thermodynamic effects and not by advection or deformation) is approximately $780 \mathrm{~km}^{3} \mathrm{yr}^{-1}$ for the entire base simulation (Table 3) and approximately $830 \mathrm{~km}^{3} \mathrm{yr}^{-1}$ for 2004 and 2005. The simulated flux for 2004 and 2005 is similar to observation-based estimates for the same period (winters 2004 and 2005) for net ice export $\left[\sim 800 \mathrm{~km}^{-3} \mathrm{yr}^{-1}\right.$; Fig. 12a in Comiso et al. (2011)] and polynya ice production $\left[\sim 640 \mathrm{~km}^{3} \mathrm{yr}^{-1}\right.$; Fig. 13 in Comiso et al. (2011)].

There is a great deal of interannual variability in the summer sea ice extent (Figs. 2 and 4), but a $20 \%$ increase in wind strength slightly increases the mean extent (i.e., less summer sea ice area) and duration of the summertime Ross Sea polynya, while a $20 \%$ decrease has the opposite effect (Fig. 4). Differences in the minimum sea ice area between the base simulation and simulations where only the winds were changed are not statistically significant, but differences in open water duration (time of ice area $<2 \times 10^{5} \mathrm{~km}^{2}$ ) are significant $(p<0.05)$. Increased wind strength enhances advection of ice off the continental shelf but also significantly increases thermodynamic production of ice (Table 3 ). Decreased wind strength reduces the thermodynamic creation of ice (Table 3). A reduction in atmospheric temperature of $1^{\circ} \mathrm{C}$ increases summer ice extent and thermodynamic ice production (Table 3 ) and reduces the duration of the summer open water area (Fig. 4). A $20 \%$ increase in the wind speed, combined with a decrease in air temperature, leads to a small net increase in the summer sea ice extent (Fig. 4) and to a greater increase in thermodynamic ice production (Table 3 ).

\section{b. Effect on water mass transport and volume}

The Ross Sea circulation model accurately simulates the locations of the CDW intrusions [e.g., Fig. 7 in Dinniman et al. (2011); see Fig. S2 in the supplemental material]. Observation-based estimates of total CDW transport onto the Ross Sea continental shelf are limited to a few locations and short periods. The simulated MCDW transport along the western slope of Pennell Bank over a 2-week period in the summer of $2011[0.22 \pm 0.03 \mathrm{~Sv}$ $\left(1 \mathrm{~Sv} \equiv 10^{6} \mathrm{~m}^{3} \mathrm{~s}^{-1}\right)$; McGillicuddy et al. 2015 , see their 
TABLE 3. Results from prescribed forcing model simulations (Table 1). "Shelf" refers to the portions of the Ross Sea continental shelf not below an ice shelf. Negative heat flux means heat transport toward the ocean surface. Note that a slightly different definition $\left(T<-0.5^{\circ} \mathrm{C}\right.$ and $S>34.65$ ) was used for the HSSW in the off-shelf flux than in the total HSSW volume calculation (which followed Orsi and Wiederwohl 2009) as a result of the shelf volume definition being too cold for water advecting off the shelf.

\begin{tabular}{|c|c|c|c|c|c|c|c|}
\hline Simulation & $\begin{array}{c}\text { New ice created } \\
\text { over shelf } \\
\left(\mathrm{km}^{3} \mathrm{yr}^{-1}\right)\end{array}$ & $\begin{array}{c}\text { Mean dye value } \\
\text { over shelf } \\
\text { (dye units) }\end{array}$ & $\begin{array}{c}\text { Mean dye value } \\
\text { over shelf } \\
\text { (top } 50 \mathrm{~m} ; \\
\text { dye units) }\end{array}$ & $\begin{array}{l}\text { Mean heat flux } \\
\text { through } 200 \mathrm{~m} \\
\text { over shelf } \\
\left(\mathrm{W} \mathrm{m}^{-2}\right)\end{array}$ & $\begin{array}{c}\text { Mean HSSW } \\
\text { volume } \\
\left(10^{4} \mathrm{~km}^{3}\right)\end{array}$ & $\begin{array}{c}\text { Mean HSSW } \\
\text { flux off } \\
\text { shelf (Sv) }\end{array}$ & $\begin{array}{c}\text { Mean RIS basal } \\
\text { melt rate } \\
\left(\mathrm{cm} \mathrm{yr}^{-1} / \mathrm{Gt} \mathrm{yr}^{-1}\right)\end{array}$ \\
\hline Base & 779 & 33.4 & 29.3 & -3.76 & 4.64 & 1.20 & $21.1 / 91.1$ \\
\hline Wind $* 0.8$ & 485 & 30.0 & 24.9 & -2.26 & 4.15 & 0.74 & $18.8 / 81.4$ \\
\hline Wind*1.2 & 1032 & 35.8 & 32.6 & -6.31 & 5.23 & 1.66 & $23.0 / 99.2$ \\
\hline $\mathrm{T}-1.0 \mathrm{C}$ & 833 & 35.1 & 31.6 & -3.93 & 4.94 & 1.31 & $20.0 / 86.3$ \\
\hline $\mathrm{T}-1.0 \mathrm{C}+$ & 1097 & 38.5 & 35.7 & -6.54 & 5.49 & 1.73 & 21.8/94.0 \\
\hline
\end{tabular}

supplemental material] matched observations made at this location over the same period (0.24Sv; Kohut et al. 2013), suggesting that the volume input is realistically captured in the simulations. This agreement supports using simulated dye tracer distributions to represent the volume flux of CDW onto the Ross Sea continental shelf.

For the base simulation, dye input to the Ross Sea continental shelf leads to an increase in the dye concentration until it reaches an approximate steady state after about six years (Fig. S3 in the supplemental material), when the transport of dye off the shelf (either in the surface layers over the shelf break or at depth at the western model open boundary) balances the transport of dye onto the shelf. Six years approximately matches estimates of the residence time of waters on the Ross Sea continental shelf [e.g., four years in Trumbore et al. (1991)]. A 20\% reduction or increase in wind strength decreased and increased, respectively, the flow of water in the shelf break current and the CDW input to the continental shelf (Table 3 ). A reduction in atmospheric temperature also produces an increase in CDW input relative to the Base case (Table 3 ). The largest input of CDW relative to the Base case is obtained from the combination of increased wind strength and reduced atmospheric temperature (Table 3 ).

CDW typically flows onto the Ross Sea continental shelf below $200 \mathrm{~m}$ (Orsi and Wiederwohl 2009), so the presence of CDW dye in the upper part of the water column over the shelf results from both advection and vertical mixing. Vertical mixing was estimated from the simulated dye concentration in the upper $50 \mathrm{~m}$ of the water column and the vertical diffusive heat flux across $200 \mathrm{~m}$ (Table 3). As with the total water column CDW, strengthening winds and decreasing air temperature both lead to an increase in the CDW in the upper water column over the continental shelf (Table 3 ). The shelfaveraged heat flux through $200 \mathrm{~m}$ (Table 3) shows increased vertical mixing from increased wind and decreased air temperature.
The volume of HSSW (defined by salinity $>34.62$ and temperature $<-1.85^{\circ} \mathrm{C}$ ) in the Ross Sea is estimated from observations to be $7.16 \times 10^{4} \mathrm{~km}^{3}$ (Orsi and Wiederwohl 2009). Using the same criterion, the mean volume of HSSW estimated from the base simulation is $4.64 \times 10^{4} \mathrm{~km}^{3}$, which is about $35 \%$ lower than the Orsi and Wiederwohl (2009) estimate, which is based on a climatology that is heavily weighted by summer observations. The modeled distribution of HSSW (Fig. S4 in the supplemental material) is similar to observations [see Fig. 8 in Orsi and Wiederwohl (2009); note the observed layer thickness estimate covers water masses in addition to HSSW], but the layer is thinner. The simulated HSSW volume exhibits a seasonal cycle, with a maximum in austral spring (Fig. 5) rather than in summer, suggesting that too little HSSW is produced in the simulation. Modified wind strength shifts the timing of the fall minimum (Fig. 5) and leads to decreases (reduced winds) or increases (strengthened winds) in the mean HSSW volume (Table 3). Decreased air

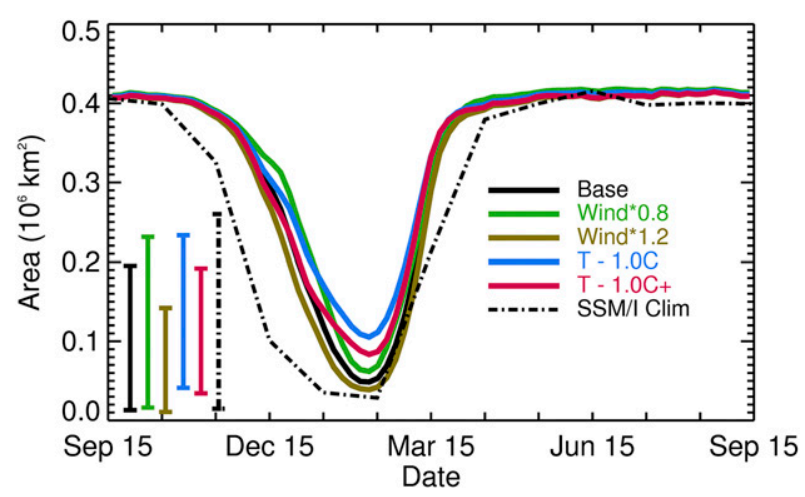

FIG. 4. Climatology over the entire 15 years of the simulated (different colored solid lines) and monthly observed SSM/I (dashed-dotted line) sea ice area $\left(10^{6} \mathrm{~km}^{2}\right)$ calculated for the continental shelf for the prescribed change simulations (Table 1). The range of the summer minimum ice area is shown for each simulation and SSM/I (vertical bars). 


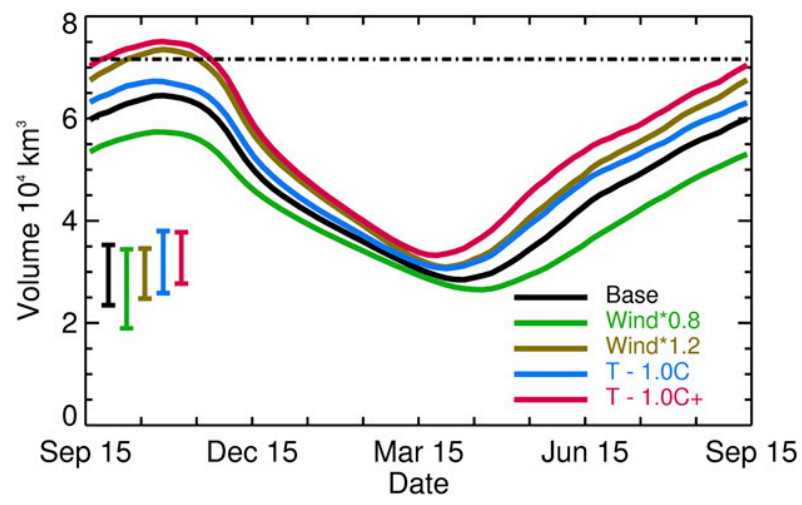

FIG. 5. Climatology of modeled volume of HSSW on the Ross Sea continental shelf over the entire 15 years of the prescribed change simulations. The dashed-dotted line is the estimate $\left(7.16 \times 10^{4} \mathrm{~km}^{3}\right)$ from Orsi and Wiederwohl (2009). The range of the minimum HSSW volume is shown for each simulation (vertical bars).

temperature also produced an increase (Table 3) in the mean volume of HSSW. The relative effect of modified environmental forcing is also apparent in the off-shelf flux of HSSW (calculated by summing the volume fluxes across the shelf break in any model grid cells at the shelf break where the top of the grid cell is below $200 \mathrm{~m}$, the temperature is less than $-0.5^{\circ} \mathrm{C}$, and the salinity is greater than 34.65), which increased with increasing wind strength and decreasing air temperature (Table 3 ).

\section{c. Effect on Ross Ice Shelf basal melt}

The RIS basal melt rate climatology constructed from the base simulation shows an annual cycle with a maximum in summer and mean of $21.1 \mathrm{~cm} \mathrm{yr}^{-1}\left(91.1 \mathrm{Gt} \mathrm{yr}^{-1}\right.$; Fig. 6 and Table 3), which is at the upper range of observed melt rate estimates of $6-22 \mathrm{~cm} \mathrm{yr}^{-1}$ (Jacobs et al. 1992; Smethie and Jacobs 2005; Loose et al. 2009; Rignot et al. 2013; Depoorter et al. 2013; Liu et al. 2015). The spatial distribution of the mean basal melt rate (Fig. 7) qualitatively matches satellite-based estimates (Moholdt et al. 2014) with higher melt rates at the ice shelf front, immediately east of Ross Island, where Byrd Glacier feeds into the ice shelf (immediately south of $80^{\circ} \mathrm{S}$ on the west side of the ice shelf) and in the extreme southern end of the cavity. Modifications to the winds produce increases (stronger winds) and decreases (weaker winds) in the basal melt (Fig. 6 and Table 3) that occur throughout the year. The stronger winds increase the transport of the relatively warm CDW onto the continental shelf (Table 3), which delivers more heat to the cavity beneath the RIS throughout the year. Decreased atmospheric temperature decreases basal melt rate in the summer, but the melt rate is similar to that obtained from the Base case the rest of the year (Fig. 6). The

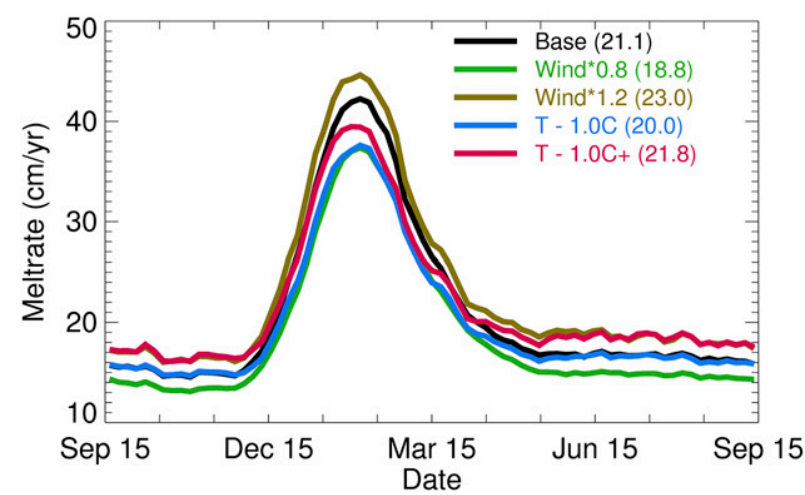

FIG. 6. Climatology over the entire 15-yr simulation of the areaaveraged RIS basal melt rate $\left(\mathrm{cm} \mathrm{yr}^{-1}\right)$ for the prescribed change simulations. The numbers given in parentheses are the average melt rate calculated for each simulation.

spatial differences in the annual averaged basal melt (Fig. S5 in the supplemental material) are mostly along the ice shelf front or along a pathway from the open ocean along the northwestern edge of the RIS when only atmospheric temperatures are modified, but some of the differences are moved farther into the cavity when just the winds are changed.

\section{Effects of projected climate scenarios}

\section{a. Effect on sea ice}

The simulated sea ice area obtained using the ECHAM5 winds is similar to that obtained from the prescribed forcing cases, showing maximum extent in austral winter and decreases with the seasonal expansion of the Ross Sea polynya (Fig. 8). However, the twentieth-century simulation has excess ice in summer, and the Ross Sea polynya expands later in the year, compared to observations (Fig. 8) and the Base case simulation with the prescribed forcing (Fig. 4). This difference possibly results from the lower resolution of the ECHAM5 winds (spectral T63 at $\sim 1.875^{\circ}$ ) relative to the ERA-Interim winds ( $\sim 80 \mathrm{~km})$. The winter sea ice concentration for 2050 is similar to the Twentieth century case, but with a summer decrease that is $40 \%$ larger (Fig. 8). There is also significantly lower (16\%; Table 4) net production of ice over the shelf by 2050 .

The timing of the summer polynya formation is shifted with an extension of the period of open water over much of the shelf by approximately 25 days (Fig. 8). The trend continues in the 2100 simulation, with the ice-free area being slightly greater and remaining longer (Fig. 8), and a further small (4\%) reduction in the net production of ice over the shelf (Table 4). The addition of freshening to the 2050 and 2100 simulations results in almost 


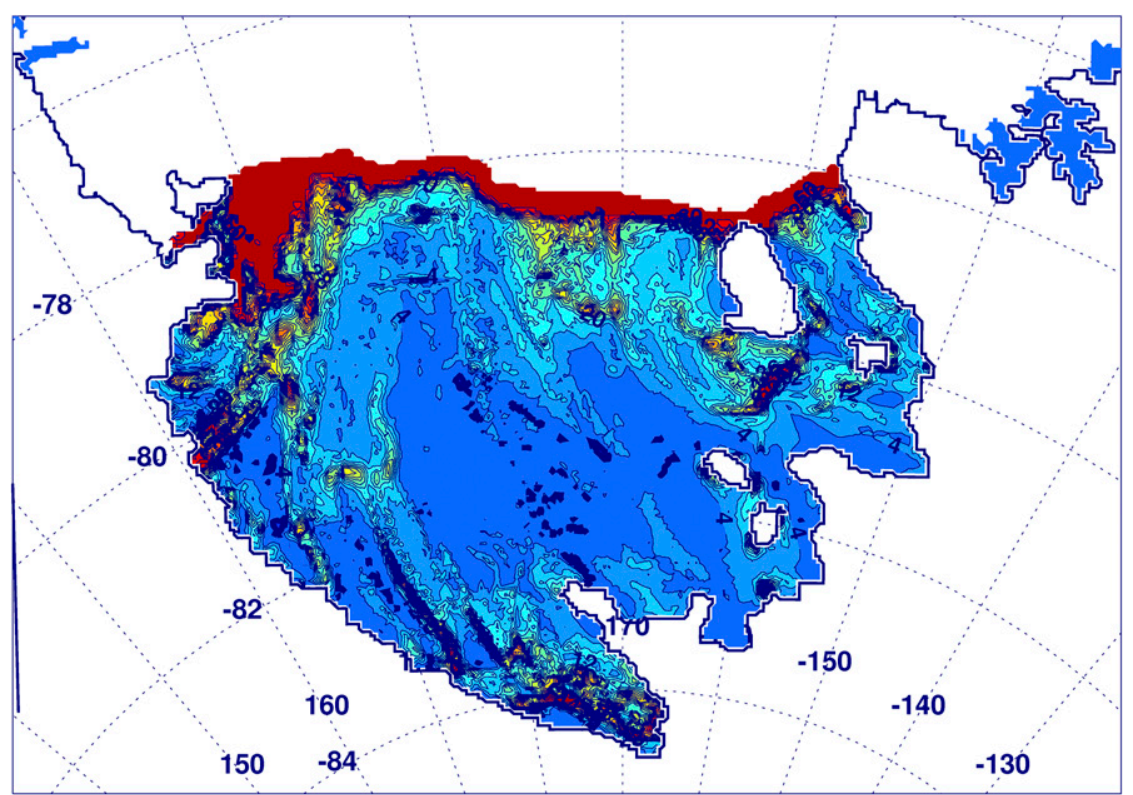

\section{Mean Basal Melt (Base) (cm/yr)}

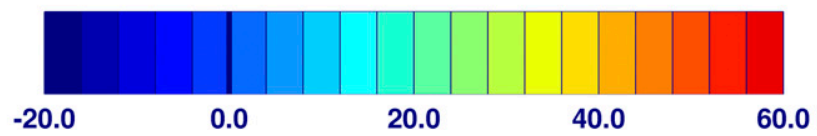

FIG. 7. Mean basal melt rate $\left(\mathrm{cm} \mathrm{yr}^{-1}\right)$ obtained from the Base case simulation.

no additional change in the sea ice extent (Fig. 8), but it does increase the net production of sea ice over the continental shelf (Table 4).

\section{b. Effect on water mass transport and volume}

The simulated mean dye concentration transported onto the continental shelf approaches steady state after a little over four years for all the projected change simulations (not shown). The 2050 simulation has less transport of $\mathrm{CDW}$ onto the continental shelf relative to the twentieth century (Table 4). The CDW transport onto the continental shelf resulting from 2100 conditions is similar to the transport obtained for 2050 conditions (Table 4). The vertical mixing of CDW into the upper part of the water column over the continental shelf (Table 4) is reduced for 2050 conditions relative to the twentiethcentury simulation, and the 2100 conditions produce results similar to those from the 2050 simulation.

Freshening of the Ross Sea combined with 2050 forcing significantly reduces the mean CDW transported onto the shelf relative to the equivalent simulation with no freshening (Table 4). The addition of freshening to
2100 conditions also significantly reduces the CDW transport onto the shelf (Table 4 and Fig. S2). The reduction in salinity over the continental shelf and slope, with a lesser reduction in the off-shelf salinity (Fig. S6 in

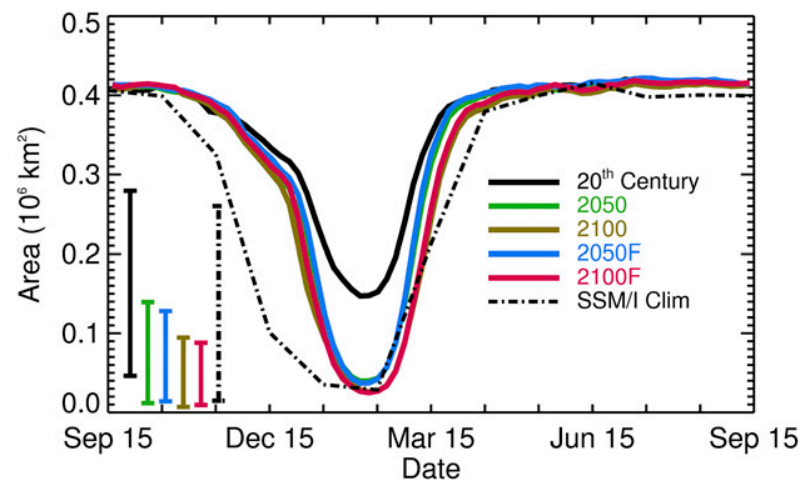

FIG. 8. Climatology of simulated and observed (SSM/I) sea ice area over the Ross Sea continental shelf for the AR4 forced simulations (Table 2). The climatology for the model cases is over the 15 years in each simulation, and that of the SSM/I is over the same 15 -yr time period as the Twentieth century case. The range of the summer minimum ice area is shown for each simulation and SSM/I (vertical bars). 
TABLE 4. As in Table 3, but for results from climate model forced simulations (Table 2).

\begin{tabular}{lcccccccc}
\hline \hline & $\begin{array}{c}\text { New ice } \\
\text { created } \\
\text { over shelf } \\
\left(\mathrm{km}^{3} \mathrm{yr}^{-1}\right)\end{array}$ & $\begin{array}{c}\text { Mean dye } \\
\text { value } \\
\text { over shelf } \\
\text { (dye units) }\end{array}$ & $\begin{array}{c}\text { Mean dye value } \\
\text { over shelf } \\
\text { (top 50 m; } \\
\text { dye units) }\end{array}$ & $\begin{array}{c}\text { Mean heat flux } \\
\text { through } 200 \mathrm{~m} \\
\text { over shelf } \\
\left(\mathrm{W} \mathrm{m}^{-2}\right)\end{array}$ & $\begin{array}{c}\text { Mean heat } \\
\text { flux through } \\
50 \mathrm{~m} \text { over } \\
\text { shelf }\left(\mathrm{W} \mathrm{m}^{-2}\right)\end{array}$ & $\begin{array}{c}\text { Mean } \\
\text { HSSW } \\
\text { volume } \\
\left(10^{4} \mathrm{~km}^{3}\right)\end{array}$ & $\begin{array}{c}\text { Mean } \\
\text { HSSW flux } \\
\text { off shelf } \\
(\mathrm{Sv})\end{array}$ & $\begin{array}{c}\text { Mean RIS } \\
\text { basal melt rate } \\
\left(\mathrm{cm} \mathrm{yr}^{-1} / \mathrm{Gt} \mathrm{yr}^{-1}\right)\end{array}$ \\
\hline $\begin{array}{c}\text { Simulation } \\
\text { century }\end{array}$ & 779 & 31.1 & 26.5 & -2.11 & -22.6 & 4.47 & 1.13 & $17.4 / 75.1$ \\
2050 & 657 & 26.5 & 21.1 & -1.95 & -18.7 & 3.99 & 0.91 \\
2100 & 630 & 26.8 & 21.5 & -1.99 & -18.7 & 3.88 & 0.85 & $19.0 / 82.3$ \\
$2050 \mathrm{~F}$ & 820 & 15.6 & 11.1 & -1.38 & -15.0 & 3.69 & 0.53 & $19.6 / 84.7$ \\
$2100 \mathrm{~F}$ & 772 & 16.3 & 11.6 & -1.38 & -15.1 & 3.64 & 0.46 & $20.3 / 87.6$ \\
\hline
\end{tabular}

the supplemental material), can lead to a slowing of the shelf break current at depth in the western Ross Sea (Fig. S7 in the supplemental material) and a reduction ( $>60 \%$ in some locations) in the vertical shear of the shelf break current (Table 5) caused by the decreased cross-front density difference (Fig. S6). The reduced shelf break current at the level of the CDW intrusions leads to the reduced CDW transport onto the shelf with the addition of freshening. The CDW flux into the upper water column is reduced with the addition of freshening, indicating reduced vertical mixing (Table 4). This reduction is shown more explicitly by examining the differences in heat flux through 50 and $200 \mathrm{~m}$ (Table 4).

The HSSW volume produced by the ECHAM5 forcing (Fig. 9 and Table 4) is slightly less than that from the Base case (Fig. 5 and Table 3). The 2050 and 2100 conditions produced a smaller mean HSSW volume (Fig. 9 and Table 4), with a shift in the timing of minimum volume to later in the fall. The addition of freshening further reduced the mean and maximum HSSW volumes, and although the minimum volume does not change much, the timing of the minimum volume shifts

TABLE 5. Effect on shelf break current due to freshening. Location refers to whether upstream of Drygalski Trough (DT) or Glomar Challenger Trough (GCT); see Fig. 1 for location. Vertical speed difference is the reduction in the mean along slope westward current from model layer 4 (above the model bottom Ekman layer) upward to model layer 18 (below the model surface Ekman layer).

\begin{tabular}{lccc}
\hline \hline Simulation & Location & $\begin{array}{c}\text { Mean depth-averaged } \\
\text { westward velocity and } \\
\text { std dev }\left(\mathrm{cm} \mathrm{s}^{-1}\right)\end{array}$ & $\begin{array}{c}\text { Vertical speed } \\
\text { difference } \\
\left(\mathrm{cm} \mathrm{s}^{-1}\right)\end{array}$ \\
\hline 2050 & DT & $13.8 \pm 2.7$ & 19.5 \\
$2050 \mathrm{~F}$ & DT & $14.3 \pm 2.3$ & 14.0 \\
2050 & GCT & $7.5 \pm 2.9$ & 12.7 \\
$2050 \mathrm{~F}$ & GCT & $6.0 \pm 2.6$ & 4.7 \\
2100 & DT & $13.8 \pm 2.8$ & 19.8 \\
$2100 \mathrm{~F}$ & DT & $14.4 \pm 2.5$ & 14.1 \\
2100 & GCT & $7.8 \pm 3.0$ & 13.1 \\
$2100 \mathrm{~F}$ & GCT & $6.0 \pm 2.5$ & 5.2 \\
\hline
\end{tabular}

to later in the fall. The flux of HSSW off the continental shelf, which affects the formation of AABW, is reduced for 2050 and 2100 conditions (Table 4), and the addition of freshening further reduces the off-shelf transport greatly, by as much as $59 \%$.

\section{c. Effect on Ross Ice Shelf basal melt}

The simulated mean melt rate over the entire base of the RIS obtained using twentieth-century ECHAM5 wind and atmospheric conditions shows an annual cycle with a summer maximum (Fig. 10) and mean (17.4 $\mathrm{cm} \mathrm{yr}^{-1}$; Table 4) that is less than that in the prescribed forcing Base case (21.1 $\mathrm{cm} \mathrm{yr}^{-1}$; Table 3). The 2050 and 2100 conditions produced small increases in the mean basal melt (19.0 and $19.6 \mathrm{~cm} \mathrm{yr}^{-1}$; Table 4), with almost all the increase occurring during the summer (Fig. 10). The addition of freshening slightly increases the basal melt rate (19.9 and $20.3 \mathrm{~cm} \mathrm{yr}^{-1}$; Table 4), with the additional increase also occurring in the summer. The increased summer atmospheric temperatures in 2050 and 2100 lengthen the period of open water in front of the RIS

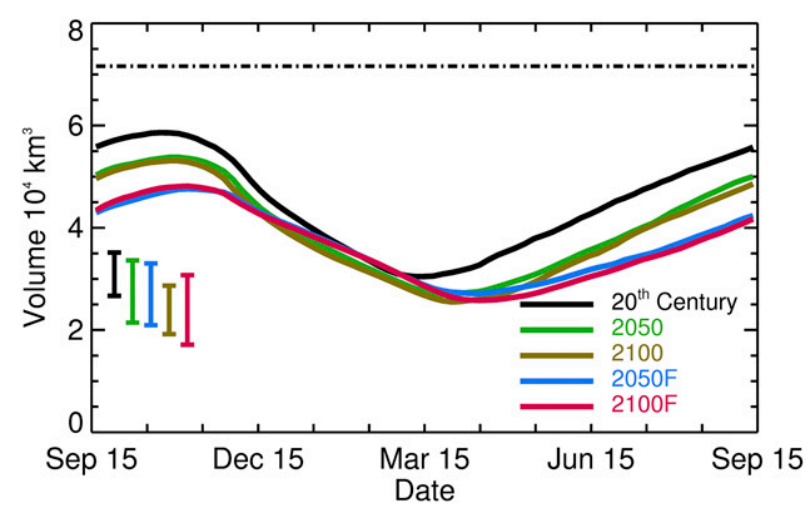

FIG. 9. Climatology of modeled volume of HSSW for the AR4 forced simulations. The climatology for the model cases is over the 15 years in each simulation. The dashed-dotted line is the estimate $\left(7.16 \times 10^{4} \mathrm{~km}^{3}\right)$ from Orsi and Wiederwohl (2009). The range of the minimum HSSW volume is shown for each simulation (vertical bars). 


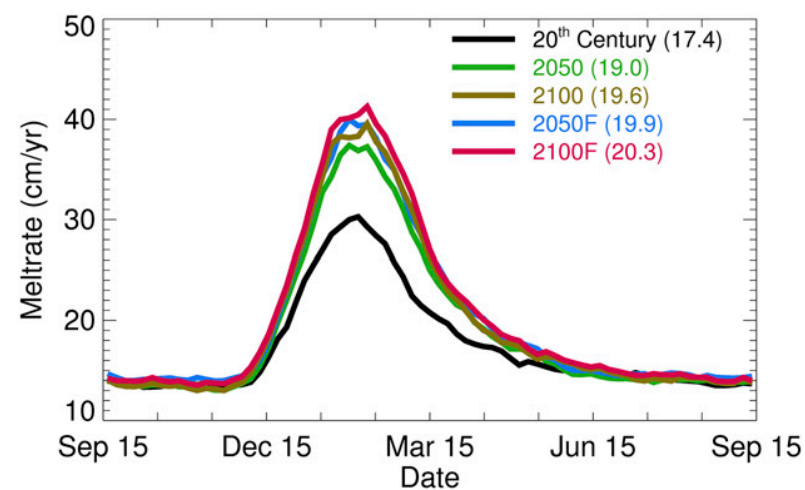

FIG. 10. As in Fig. 6, but for the AR4 forced simulations.

(Fig. 8) and increase the temperature of the summer surface water in the polynya, which in turn increases the summer melt, primarily near the ice shelf front (Fig. 11) but has little impact the rest of the year.

Freshening of the Ross Sea reduces the transport of CDW onto the continental shelf (Table 4), but it also reduces the vertical mixing of MCDW into surface waters over the continental shelf, resulting in less heat removal from the MCDW (Table 4). These two effects have different time scales. The reduced vertical mixing due to freshening is an almost immediate effect, producing an initial increase $\left(2.2 \mathrm{~cm} \mathrm{yr}^{-1}\right.$ over the first four years) in the basal melt relative to 2050 and 2100 conditions without freshening. At longer time scales, the reduction in CDW transport onto the shelf eventually balances most of the reduced mixing out of MCDW heat, which results in a small net change in the basal melt.

\section{Discussion}

\section{a. Effect on sea ice}

The prescribed forcing cases showed that increased wind speed, with no other atmospheric changes, reduced summer sea ice concentrations over the Ross Sea continental shelf and increased the duration and extent of summer open water. As the observed southerlies over the Ross Sea have strengthened in recent years (Turner

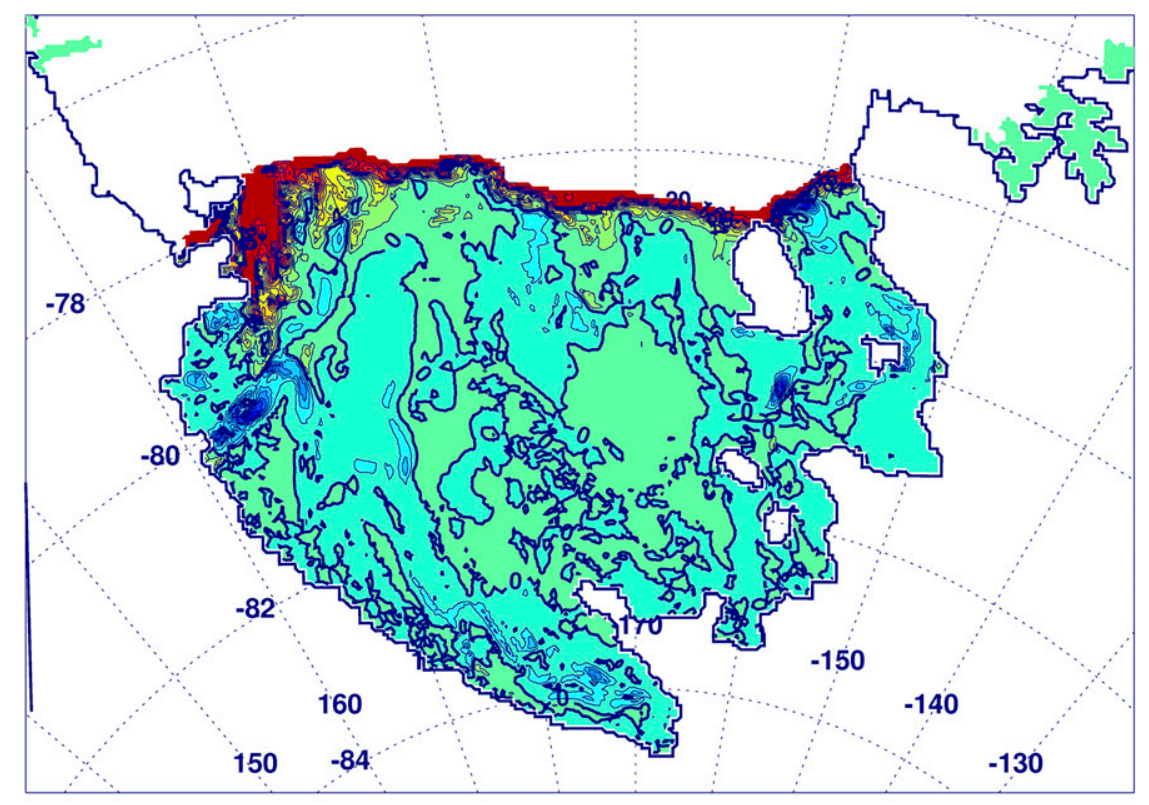

Delta Basal Melt (2100 - Current) (cm/yr)

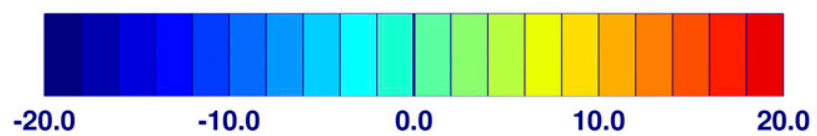

FIG. 11. Average over the entire 15-yr simulation of the difference in basal melt rate $\left(\mathrm{cm} \mathrm{yr}^{-1}\right)$ between the 2100 case and the Twentieth century case. 
et al. 2009; Fan et al. 2014; Zhang 2014), this simulated response seems counterintuitive relative to recent observed decreases in summer open water (Stammerjohn et al. 2012). However, between 1992 and 2013, small increases in the number of ice-free days within the Ross Sea and Terra Nova Bay polynyas have been observed (Schine et al. 2016). Also, sea ice extent is influenced by air temperature as well as wind strength. The recent wind changes over the Ross Sea represent an increase in cold, southerly winds blowing over the Ross Ice Shelf before crossing the Ross Sea. Stronger winds result in colder atmospheric temperatures and lead to the observed cooling and enhanced ice formation (Comiso 2010; Comiso et al. 2017). Simulations that combined increased wind strength with spatially uniform decreases in the air temperatures produced realistic increases in summer sea ice concentrations.

The projected forcing scenarios for 2050 have stronger southerlies over most of the Ross Sea continental shelf (Fig. S8 in the supplemental material) but warmer atmospheric temperatures. The warmer summer temperatures dominate the sea ice response, producing increases in the duration and extent of the summer open water. Thus, projected sea ice responses in the Ross Sea are dependent on processes that moderate atmospheric temperatures, such as increasing greenhouse gases (e.g., Dwyer et al. 2012), rather than local atmospheric advective cooling.

\section{b. Effect on HSSW volume and transport}

The simulated HSSW volume is low relative to that estimated from observations (Fig. 5). The ERA-Interim winds used to force the model do not capture the strongest wind events in the Ross Sea (Dale et al. 2017; Mack et al. 2017), which limits simulated summer mixed layers (Mack et al. 2017) and likely limits modeled Ross Sea polynya extent (Dale et al. 2017) and maximum sea ice production in winter. However, the simulated net local ice production agrees somewhat with observations, suggesting that the discrepancy may also result from inaccuracies in the simulated volume of freshwater coming onto the shelf. Nevertheless, the prescribed forcing simulations showed that increasing the wind strength and decreasing the atmospheric temperature both increased the volume of HSSW on the shelf. The 2050 and 2100 conditions result in a smaller mean simulated volume of HSSW than obtained for twentiethcentury conditions (Fig. 9 and Table 4). Freshening of the Ross Sea at the boundaries leads to shelfwide freshening at depth (Fig. S6) and further reduces the HSSW volume.

Tides at the Ross Sea shelf break enhance mixing of shelf waters with CDW and, thus, are key contributors to
AABW formation in this region (Whitworth and Orsi 2006; Padman et al. 2009). The Ross Sea circulation model used in this study does not include tides, which affects estimates of AABW formation for the different forcing scenarios. However, the off-shelf transport of HSSW, a precursor of AABW formation, can be estimated from the simulations and used to infer changes in AABW formation. For the prescribed forcing simulations, increasing wind strength increased the flux of HSSW off the shelf, which is consistent with observational (Gordon et al. 2015) and model (Stewart and Thompson 2012, 2013) results that show that the magnitude of the winds along the shelf break is an important factor in the export of shelf water from the Ross Sea. However, Gordon et al. (2015) proposed that a strengthening of the polar easterlies actually reduces the off-shelf flux of HSSW. The flux of HSSW off the continental shelf is reduced in simulations that used the 2050 and 2100 conditions. The addition of freshening further reduced the off-shelf HSSW by as much as $59 \%$. This implies that freshening of the Ross Sea, rather than warming atmospheric temperatures, is potentially the largest contribution to reductions in AABW formation through its effect on HSSW formation. The observed decrease in the volume of AABW created near the Ross Sea since the 1980s has been attributed to freshening of the Ross Sea (Rintoul 2007; Purkey and Johnson 2012; Shimada et al. 2012).

\section{c. Effect on RIS basal melt}

Colder atmospheric temperatures reduce the summer open ocean area adjacent to the ice shelf, allowing the surface water adjacent to the RIS to be colder during summer. The surface water that is then transported underneath RIS contains less heat, leading to a reduction in the summertime basal melt rate. Observations show that seasonal temperature changes in the surface waters north of the RIS have a significant effect on changing the basal melt along the RIS Front (Horgan et al. 2011; Arzeno et al. 2014) and underneath the McMurdo Ice Shelf (adjacent to the northwest corner of the RIS; Robinson and Williams 2012; Stern et al. 2013). These observations support the simulation results showing that changes in atmospheric temperatures influence the RIS melt (at least near the RIS Front) through modifications to surface waters adjacent to the RIS.

Simulations with the Ross Sea circulation model that include tides show increased mean basal melt rates of approximately $25 \%-30 \%$ (Arzeno et al. 2014) and approximately $15 \%$ (Mack 2017). This tidal enhancement can modify the magnitude of the simulated basal melt rates obtained in this study. The potential effects of tides 
on CDW import and HSSW export for present and projected atmospheric and ocean conditions in the Ross Sea remain to be determined.

The 5-km horizontal resolution of the circulation model used in this study does not resolve baroclinic eddies over the continental shelf (Hallberg 2013; Mack 2017) and no eddy parameterization was used. The formation of eddies along the RIS Front, which is related to basal melt rate, has been suggested to be important in the lateral transport of glacial meltwater into the Ross Sea interior ( $\mathrm{Li}$ et al. 2017). Resolving these eddies may contribute to modifications in basal melt rate, as well as to better understanding of the fate of glacial meltwater. Increasing the horizontal resolution of the Ross Sea circulation model to $1.5 \mathrm{~km}$ significantly impacted mesoscale eddy formation (Mack 2017) but had minimal effect on glacial melt [e.g., Table 5 in Mack et al. (2017)] or mean summer mixed layer depths (Mack et al. 2017). However, the formation of eddies with the increased resolution affects other shelf circulation properties, such as deep winter vertical mixing (Mack et al. 2017). The effects of these indirect feedbacks between circulation and basal melt rate remain to be assessed.

The primary contribution to the basal melt provided by the idealized stronger winds is advection of more warm CDW onto the continental shelf, which delivers more heat to the cavity beneath the RIS throughout the year. A modeling study (Dinniman et al. 2012) of the western Antarctic Peninsula (WAP) shelf found that increased winds could sometimes lead to a decrease in basal melting (i.e., for the George VI Ice Shelf) because of heat loss in CDW from vertical mixing during transport across the continental shelf toward the ice shelf cavity. However, heat loss from CDW by vertical mixing on the Ross Sea shelf is larger than along the WAP, and the relative increase in heat loss with stronger winds is thus less in the Ross Sea. The increase in advection is more important to the delivery of CDW/MCDW heat to the RIS than the increase in vertical mixing. The simulations with modified atmospheric temperatures show differences in the annual averaged basal melt along the ice shelf front or along a pathway from the open ocean along the northwestern edge of the RIS. Increasing winds move some of these differences farther into the ice shelf cavity, suggesting that the effect of increased winds is to transport MCDW farther into the RIS cavity. However, observations to confirm this result are needed.

Timmermann and Hellmer (2013) used ECHAM5 forcing from several AR4 scenarios (including the A1B scenario), as well as forcing fields from the Hadley Centre Coupled Model, version 3 (HadCM3), to simulate conditions through the end of the twenty-first century using a global ocean-ice model. The simulated RIS melt showed little change for the ECHAM5-forced simulations, similar to the results shown here, whereas the HadCM3 scenario simulations all showed increased RIS melt rates after 2050. This difference is attributed to a colder and saltier Ross Sea continental shelf, resulting from more convection on the shelf in the ECHAM5 simulations relative to the HadCM3 simulations. Timmermann and Hellmer (2013) note that their results did not provide clear guidance on which model forcing is more realistic, which underscores the difficulty in attributing changes that are based on results from different forcings.

Kusahara and Hasumi (2013) forced a circumpolar sea ice-ice shelf-ocean model with idealized changes in the air temperatures and, even with a $6^{\circ} \mathrm{C}$ increase in air temperature [which is greater than the warming in any of the HadCM3 fields used by Timmermann and Hellmer (2013)], the increase in basal melt rates for the RIS was only $7.5 \%$. In their simulation, sea ice formation over the Ross Sea (and other cold water shelves) was sufficient to maintain strong convection over the continental shelf and remove much of the MCDW heat. Timmermann and Hellmer (2013) noted that both sets of simulations show that future states of large cold water ice shelves are dependent on water mass changes produced by changes in salt input from local sea ice formation on the continental shelf. The simulations from this study advance this idea by showing that freshening is a potential significant contributor to increased basal melt rate of the RIS through its reduction of mixing and consequent retention of heat by MCDW. However, this is partially balanced by reduced advection of CDW onto the continental shelf, which leads to only around a $4 \%-5 \%$ further increase in the basal melt as a result of the freshening. Nevertheless, consistent with Timmermann and Hellmer (2013), future changes in RIS basal melt are likely to result at least as much from changes in local mixing and its effect on the shelf water masses as from changes in inputs of warm off-shelf waters.

\section{Summary}

Atmospheric warming and changes in wind speed (increases and decreases) and direction are projected for the Ross Sea over the next century. The prescribed forcing simulations show that cooler air temperatures increase the summer sea ice over the continental shelf and the transport of MCDW to the upper-shelf waters and imply the opposite (warmer air temperatures reduce the summer sea ice and the transport of MCDW to the upper-shelf waters), although this could be balanced by 
changes in winds. Results from simulations forced with winds and air temperatures from the MPI ECHAM5 model showed reduced summer sea ice, transport of CDW onto the continental shelf and mixing of MCDW into the upper waters, and increased basal melt rate of the RIS by the middle and end of the twenty-first century, compared to the end of the twentieth century.

There has also been an observed freshening of the Ross Sea over the last 50 years, and it has been proposed that this is a signature of increased meltwater advected from the Amundsen Sea. A freshening of the water advected into the model domain for the ECHAM5 simulations did not have a significant effect on the simulated sea ice extent for the middle and end of the twenty-first century. However, freshening reduces the MCDW that is mixed into the upper waters over the shelf, leading to reductions in the heat lost from the MCDW on the shelf and the volume of SW produced and advected off the shelf. The freshening also reduces the density gradients across the slope front in some places, thus reducing the transport of CDW and heat onto the continental shelf. The balance between increased heat retained in the on-shelf MCDW and reduced advection of warm CDW onto the shelf is a critical determinant of the RIS basal melt.

The coupled sea ice-ocean-ice shelf model provided a view of the range of possible outcomes for a future Ross Sea in response to projected atmospheric changes. Some of the simulated outcomes, such as reduced HSSW formation and increased RIS basal melt rate, have important but poorly constrained consequences for the global thermohaline circulation. The response of the Ross Sea to remote forcing, such as freshening from upstream sources, requires understanding of its connectivity to other Antarctic coastal regions and land ice and highlights the importance of including realistic lateral boundary conditions (as opposed to climatological conditions) for limited area ocean model projections, even for time scales over which little change in the offshore boundary is expected. Reductions in sea ice and associated changes to upper water column dynamics are likely to also affect the Ross Sea ecosystem (Smith et al. 2014; Kaufman et al. 2017). Thus, the future Ross Sea will be the result of iceocean-atmosphere feedbacks that couple processes at regional, circum-Antarctic, and global scales.

Acknowledgments. This research was supported by the National Science Foundation under Grants OCE0927797, ANT-0944174, and ANT-0944254 and by the Turing High Performance Computing cluster at Old Dominion University. The AMPS data were provided by John Cassano, and AMPS is supported by U.S. National Science Foundation support to NCAR, The
Ohio State University, and the University of Colorado. Stefanie Mack provided the enhanced version of the Ross Sea model used in this study. Comments from three anonymous reviewers greatly improved the manuscript. This is Virginia Institute of Marine Science Contribution Number 3716.

\section{REFERENCES}

Aoki, S., S. R. Rintoul, S. Ushio, S. Watanabe, and N. L. Bindoff, 2005: Freshening of the Adélie Land Bottom Water near $140^{\circ}$ E. Geophys. Res. Lett., 32, L23601, https://doi.org/10.1029/ 2005 GL024246.

Arndt, J. E., and Coauthors, 2013: The International Bathymetric Chart of the Southern Ocean (IBCSO) version 1.0-A new bathymetric compilation covering circum-Antarctic waters Geophys. Res. Lett., 40, 3111-3117, https://doi.org/10.1002/ $\operatorname{grl} .50413$.

Arzeno, I. B., R. C. Beardsley, R. Limeburner, B. Owens, L. Padman, S. R. Springer, C. L. Stewart, and M. J. M. Williams, 2014: Ocean variability contributing to basal melt rate near the ice front of Ross Ice Shelf, Antarctica.J. Geophys. Res. Oceans, 119, 4214-4233, https://doi.org/10.1002/2014JC009792.

Bracegirdle, T. J., and D. B. Stephenson, 2012: Higher precision estimates of regional polar warming by ensemble regression of climate model projections. Climate Dyn., 39, 2805-2821, https://doi.org/10.1007/s00382-012-1330-3.

Bromwich, D. H., A. J. Monaghan, K. W. Manning, and J. G. Powers, 2005: Real-time forecasting for the Antarctic: An evaluation of the Antarctic Mesoscale Prediction System (AMPS). Mon. Wea. Rev., 133, 579-603, https://doi.org/10.1175/ MWR-2881.1.

Budgell, P., 2005: Numerical simulation of ice-ocean variability in the Barents Sea region: Towards dynamical downscaling. Ocean Dyn., 55, 370-387, https://doi.org/10.1007/ s10236-005-0008-3.

Budillon, G., P. Castagno, S. Aliani, G. Spezie, and L. Padman, 2011: Thermohaline variability and Antarctic bottom water formation at the Ross Sea shelf break. Deep-Sea Res. I, 58, 1002-1018, https://doi.org/10.1016/j.dsr.2011.07.002.

Comiso, J. C., 2010: Polar Oceans from Space. Atmospheric and Oceanographic Sciences Library Series, Vol. 41, Springer, 507 pp., https://doi.org/10.1007/978-0-387-68300-3.

_, R. Kwok, S. Martin, and A. L. Gordon, 2011: Variability and trends in sea ice extent and ice production in the Ross Sea. J. Geophys. Res., 116, C04021, https://doi.org/10.1029/ 2010JC006391.

- R. A. Gersten, L. V. Stock, J. Turner, G. J. Perez, and K. Cho, 2017: Positive trend in the Antarctic sea ice cover and associated changes in surface temperature. J. Climate, 30, 22512267, https://doi.org/10.1175/JCLI-D-16-0408.1.

Connolley, W. M., and T. J. Bracegirdle, 2007: An Antarctic assessment of IPCC AR4 coupled models. Geophys. Res. Lett., 34, L22505, https://doi.org/10.1029/2007GL031648.

Dale, E. R., A. J. McDonald, J. H. J. Coggins, and W. Rack, 2017: Atmospheric forcing of sea ice anomalies in the Ross Sea polynya region. The Cryosphere, 11, 267-280, https://doi.org/ 10.5194/tc-11-267-2017.

Dee, D. P., and Coauthors, 2011: The ERA-Interim reanalysis: Configuration and performance of the data assimilation system. Quart. J. Roy. Meteor. Soc., 137, 553-597, https://doi.org/ 10.1002/qj.828. 
Depoorter, M. A., J. L. Bamber, J. A. Griggs, J. T. M. Lenaerts, S. R. M. Ligtenberg, M. R. van den Broeke, and G. Moholdt, 2013: Calving fluxes and basal melt rates of Antarctic ice shelves. Nature, 502, 89-92, https://doi.org/10.1038/nature1256.

Ding, Q., E. J. Steig, D. S. Battisti, and M. Küttel, 2011: Winter warming in West Antarctica caused by central tropical Pacific warming. Nat. Geosci., 4, 398-403, https://doi.org/10.1038/ ngeo1129.

Dinniman, M. S., J. M. Klinck, and W. O. Smith Jr., 2007: Influence of sea ice cover and icebergs on circulation and water mass formation in a numerical circulation model of the Ross Sea, Antarctica. J. Geophys. Res., 112, C11013, https://doi.org/ 10.1029/2006JC004036.

— — - and — 2011: A model study of Circumpolar Deep Water on the West Antarctic Peninsula and Ross Sea continental shelves. Deep-Sea Res. II, 58, 1508-1523, https:// doi.org/10.1016/j.dsr2.2010.11.013.

- , - and E. E. Hofmann, 2012: Sensitivity of Circumpolar Deep Water transport and ice shelf basal melt along the West Antarctic Peninsula to changes in the winds. J. Climate, 25, 4799-4816, https://doi.org/10.1175/JCLI-D-11-00307.1.

- - L. L.S. Bai, D. H. Bromwich, K. M. Hines, and D. M. Holland, 2015: The effect of atmospheric forcing resolution on delivery of ocean heat to the Antarctic floating ice shelves. J. Climate, 28, 6067-6085, https://doi.org/ 10.1175/JCLI-D-14-00374.1.

Dwyer, J. G., M. Biasutti, and A. H. Sobel, 2012: Projected changes in the seasonal cycle of surface temperature. J. Climate, $\mathbf{2 5}$, 6359-6374, https://doi.org/10.1175/JCLI-D-11-00741.1.

Fairall, C. W., E. F. Bradley, J. E. Hare, A. A. Grachev, and J. B. Edson, 2003: Bulk parameterization of air-sea fluxes: Updates and verification for the COARE algorithm. J. Climate, 16, 571-591, https://doi.org/10.1175/1520-0442(2003)016<0571: BPOASF $>2.0 . \mathrm{CO} ; 2$

Fan, T., C. Deser, and D. P. Schneider, 2014: Recent Antarctic sea ice trends in the context of Southern Ocean surface climate variations since 1950. Geophys. Res. Lett., 41, 2419-2426, https://doi.org/10.1002/2014GL059239.

Fretwell, P., and Coauthors, 2013: Bedmap2: Improved ice bed, surface and thickness datasets for Antarctica. The Cryosphere, 7, 375-393, https://doi.org/10.5194/tc-7-375-2013.

Gordon, A. L., A. H. Orsi, R. D. Muench, B. A. Huber, E. Zambianchi, and M. Visbeck, 2009: Western Ross Sea continental slope gravity currents. Deep-Sea Res. II, 56, 796817, https://doi.org/10.1016/j.dsr2.2008.10.037.

_ B. A. Huber, and J. Busecke, 2015: Bottom water export from the western Ross Sea, 2007 through 2010. Geophys. Res. Lett., 42, 5387-5394, https://doi.org/10.1002/2015GL064457.

Gordon, L. I., L. A. Codispoti, J. C. Jennings Jr., F. J. Millero, J. M. Morrison, and C. Sweeney, 2000: Seasonal evolution of hydrographic properties in the Ross Sea, Antarctica, 1996-1997. Deep-Sea Res. II, 47, 3095-3117, https://doi.org/10.1016/ S0967-0645(00)00060-6.

Haidvogel, D. B., and Coauthors, 2008: Ocean forecasting in terrainfollowing coordinates: Formulation and skill assessment of the Regional Ocean Modeling System. J. Comput. Phys., 227, 35953624, https://doi.org/10.1016/j.jcp.2007.06.016.

Häkkinen, S., and G. L. Mellor, 1992: Modeling the seasonal variability of a coupled Arctic ice-ocean system. J. Geophys. Res., 97, 20 285-20304, https://doi.org/10.1029/92JC02037.

Hallberg, R., 2013: Using a resolution function to regulate parameterizations of oceanic mesoscale eddy effects. Ocean Modell., 72, 92-103, https://doi.org/10.1016/j.ocemod.2013.08.007.
Holland, D. M., and A. Jenkins, 1999: Modeling thermodynamic ice-ocean interactions at the base of an ice shelf. J. Phys. Oceanogr., 29, 1787-1800, https://doi.org/10.1175/1520-0485 (1999) $029<1787$ :MTIOIA $>2.0$. CO;2.

Holland, P. R., and R. Kwok, 2012: Wind-driven trends in Antarctic sea-ice drift. Nat. Geosci., 5, 872-875, https://doi.org/ 10.1038/ngeo1627.

Horgan, H. J., R. T. Walker, S. Anandakrishnan, and R. B. Alley, 2011: Surface elevation changes at the front of the Ross Ice Shelf: Implications for basal melting. J. Geophys. Res., 116, C02005, https://doi.org/10.1029/2010JC006192.

Hunke, E. C., 2001: Viscous-plastic sea ice dynamics with the EVP model: Linearization issues. J. Comput. Phys., 170, 18-38, https://doi.org/10.1006/jcph.2001.6710.

, and J. K. Dukowicz, 1997: An elastic-viscous-plastic model for sea ice dynamics. J. Phys. Oceanogr., 27, 1849-1867, https:// doi.org/10.1175/1520-0485(1997)027<1849:AEVPMF>2.0.CO;2.

Jacobs, S. S., 2004: Bottom water production and its links with the thermohaline circulation. Antarct. Sci., 16, 427-437, https:// doi.org/10.1017/S095410200400224X

_ and C. F. Giulivi, 1999: Thermohaline data and ocean circulation on the Ross Sea continental shelf. Oceanography of the Ross Sea, Antarctica, G. Spezie and G. M. R. Manzella, Eds., Springer, 3-16, https://doi.org/10.1007/978-88-470-2250-8_1.

- and _ 2010: Large multidecadal salinity trends near the Pacific-Antarctic continental margin. J. Climate, 23, 45084524, https://doi.org/10.1175/2010JCLI3284.1.

, A. L. Gordon, and J. L. Ardai, 1979: Circulation and melting beneath the Ross Ice Shelf. Science, 203, 439-443, https:// doi.org/10.1126/science.203.4379.439.

- R. Fairbanks, and Y. Horibe, 1985: Origin and evolution of water masses near the Antarctic continental margin: Evidence from $\mathrm{H}_{2}^{18} \mathrm{O} / \mathrm{H}_{2}^{16} \mathrm{O}$ ratios in seawater. Oceanology of the Antarctic Continental Shelf, S. S. Jacobs, Ed., AGU Antarctic Research Series, Vol. 43, Amer. Geophys. Union, 58-85, https://doi.org/10.1029/AR043p0059.

- , H. H. Hellmer, C. S. M. Doake, A. Jenkins, and R. Frolich, 1992: Melting of ice shelves and the mass balance of Antarctica. J. Glaciol., 38, 375-387, https://doi.org/10.1017/ S0022143000002252.

, C. F. Giulivi, and P. A. Mele, 2002: Freshening of the Ross Sea during the late 20th century. Science, 297, 386-389, https:// doi.org/10.1126/science.1069574.

Jungclaus, J. H., and Coauthors, 2006: Ocean circulation and tropical variability in the coupled model ECHAM5/MPI-OM. J. Climate, 19, 3952-3972, https://doi.org/10.1175/JCLI3827.1.

Kaufman, D. E., M. A. M. Friedrichs, W. O. Smith Jr., E. E. Hofmann, M. S. Dinniman, and J. C. P. Hemmings, 2017: Climate change impacts on southern Ross Sea phytoplankton composition, productivity, and export. J. Geophys. Res. Oceans, 122, 2339-2359, https://doi.org/10.1002/2016JC012514.

Kohut, J., E. Hunter, and B. Huber, 2013: Small-scale variability of the cross-shelf flow over the outer shelf of the Ross Sea. J. Geophys. Res. Oceans, 118, 1863-1876, https://doi.org/ 10.1002/jgrc. 20090.

Kusahara, K., and H. Hasumi, 2013: Modeling Antarctic ice shelf responses to future climate changes and impacts on the ocean. J. Geophys. Res. Oceans, 118, 2454-2475, https://doi.org/ 10.1002/jgrc.20166.

Kwok, R., 2005: Ross sea ice motion, area flux, and deformation. J. Climate, 18, 3759-3776, https://doi.org/10.1175/JCLI3507.1.

Large, W. G., J. C. McWilliams, and S. C. Doney, 1994: Oceanic vertical mixing: A review and a model with nonlocal boundary 
layer parameterization. Rev. Geophys., 32, 363-403, https:// doi.org/10.1029/94RG01872.

Li, X., D. M. Holland, E. P. Gerber, and C. Yoo, 2014: Impacts of the north and tropical Atlantic Ocean on the Antarctic Peninsula and sea ice. Nature, 505, 538-542, https://doi.org/ 10.1038/nature12945.

Li, Y., D. J. McGillicuddy Jr., M. S. Dinniman, and J. M. Klinck, 2017: Processes influencing formation of low-salinity highbiomass lenses near the edge of the Ross Ice Shelf. J. Mar. Syst., 166, 108-119, https://doi.org/10.1016/j.jmarsys.2016.07.002.

Liu, Y., J. C. Moore, X. Cheng, R. M. Gladstone, J. N. Bassis, H. Liu, J. Wen, and F. Hui, 2015: Ocean-driven thinning enhances iceberg calving and retreat of Antarctic ice shelves. Proc. Natl. Acad. Sci. USA, 112, 3263-3268, https://doi.org/ 10.1073/pnas.1415137112.

Loose, B., P. Schlosser, W. M. Smethie, and S. Jacobs, 2009: An optimized estimate of glacial melt from the Ross Ice Shelf using noble gases, stable isotopes, and CFC transient tracers. J. Geophys. Res., 114, C08007, https://doi.org/10.1029/ 2008JC005048.

Lumpkin, R., and K. Speer, 2007: Global ocean meridional overturning. J. Phys. Oceanogr., 37, 2550-2562, https://doi.org/ 10.1175/JPO3130.1.

Mack, S. L., 2017: Influence of tides and mesoscale eddies in the Ross Sea. Ph.D. dissertation, Old Dominion University, $132 \mathrm{pp}$.

—, M. S. Dinniman, D. J. McGillicuddy Jr., P. N. Sedwick, and J. M. Klinck, 2017: Dissolved iron transport pathways in the Ross Sea: Influence of tides and horizontal resolution in a regional ocean model. J. Mar. Syst., 166, 73-86, https://doi.org/ 10.1016/j.jmarsys.2016.10.008.

Marshall, J., and K. Speer, 2012: Closure of the meridional overturning circulation through Southern Ocean upwelling. Nat. Geosci., 5, 171-180, https://doi.org/10.1038/ngeo1391.

Martin, S., R. S. Drucker, and R. Kwok, 2007: The areas and ice production of the western and central Ross Sea polynyas, 1992-2002, and their relation to the B-15 and C-19 iceberg events of 2000 and 2002. J. Mar. Syst., 68, 201-214, https:// doi.org/10.1016/j.jmarsys.2006.11.008.

McGillicuddy, D. J., and Coauthors, 2015: Iron supply and demand in an Antarctic shelf ecosystem. Geophys. Res. Lett., 42, 80888097, https://doi.org/10.1002/2015GL065727.

Mellor, G. L., and L. Kantha, 1989: An ice-ocean coupled model. J. Geophys. Res., 94, $10937-10954$, https://doi.org/10.1029/ JC094iC08p10937.

Moholdt, G., L. Padman, and H. A. Fricker, 2014: Basal mass budget of Ross and Filchner-Ronne ice shelves, Antarctica, derived from Lagrangian analysis of ICESat altimetry. J. Geophys. Res. Earth Surf., 119, 2361-2380, https://doi.org/ 10.1002/2014JF003171.

Nakayama, Y., R. Timmermann, C. B. Rodehacke, M. Schröder, and H. H. Hellmer, 2014: Modeling the spreading of glacial meltwater from the Amundsen and Bellingshausen Seas. Geophys. Res. Lett., 41, 7942-7949, https://doi.org/10.1002/ 2014GL061600.

Naud, C. M., J. F. Booth, and A. D. Del Genio, 2014: Evaluation of ERA-Interim and MERRA cloudiness in the Southern Ocean. J. Climate, 27, 2109-2124, https://doi.org/10.1175/ JCLI-D-13-00432.1.

Niiler, P. P., and E. B. Kraus, 1977: One-dimensional models of the upper ocean. Modelling and Prediction of the Upper Layers of the Ocean: Proceedings of a NATO Advanced Study Institute, E. B. Kraus, Ed., Pergamon Press, 143-172.
Orsi, A. H., and T. Whitworth III, 2005: Hydrographic Atlas of the World Ocean Circulation Experiment (WOCE). Vol. 1, Southern Ocean, International WOCE Project Office, 223 pp. , and C. L. Wiederwohl, 2009: A recount of Ross Sea waters. Deep-Sea Res. II, 56, 778-795, https://doi.org/10.1016/ j.dsr2.2008.10.033.

— G. C. Johnson, and J. L. Bullister, 1999: Circulation, mixing, and production of Antarctic Bottom Water. Prog. Oceanogr., 43, 55-109, https://doi.org/10.1016/S0079-6611(99)00004-X.

— W. M. Smethie Jr., and J. L. Bullister, 2002: On the total input of Antarctic waters to the deep ocean: A preliminary estimate from chlorofluorocarbon measurements. J. Geophys. Res., 107, https://doi.org/10.1029/2001JC000976.

Padman, L., S. L. Howard, A. H. Orsi, and R. D. Muench, 2009: Tides of the northwestern Ross Sea and their impact on dense outflows of Antarctic Bottom Water. Deep-Sea Res. II, 56, 818-834, https://doi.org/10.1016/j.dsr2.2008.10.026.

Parkinson, C. L., 2002: Trends in the length of the Southern Ocean sea-ice season, 1979-99. Ann. Glaciol., 34, 435-440, https:// doi.org/10.3189/172756402781817482.

Powers, J. G., A. J. Monaghan, A. M. Cayette, D. H. Bromwich, Y.-H. Kuo, and K. W. Manning, 2003: Real-time mesoscale modeling over Antarctica: The Antarctic Mesoscale Prediction System (AMPS). Bull. Amer. Meteor. Soc., 84, 15331545, https://doi.org/10.1175/BAMS-84-11-1533.

Purkey, S. G., and G. C. Johnson, 2012: Global contraction of Antarctic Bottom Water between the 1980s and 2000s. J. Climate, 25, 5830-5844, https://doi.org/10.1175/JCLI-D-11-00612.1.

$\longrightarrow$, and — 2013: Antarctic Bottom Water warming and freshening: Contributions to sea level rise, ocean freshwater budgets, and global heat gain. J. Climate, 26, 6105-6122, https://doi.org/10.1175/JCLI-D-12-00834.1.

Rignot, E., S. Jacobs, J. Mouginot, and B. Scheuchl, 2013: Ice shelf melting around Antarctica. Science, 341, 266-270, https:// doi.org/10.1126/science.1235798.

Rintoul, S. R., 2007: Rapid freshening of Antarctic Bottom Water formed in the Indian and Pacific Oceans. Geophys. Res. Lett., 34, L06606, https://doi.org/10.1029/2006GL028550.

Robinson, N. J., and M. J. M. Williams, 2012: Iceberg-induced changes to polynya operation and regional oceanography in the southern Ross Sea, Antarctica, from in situ observations. Antarct. Sci., 24, 514-526, https://doi.org/10.1017/S0954102012000296.

Rossow, W. B., A. W. Walker, D. E. Beuschel, and M. D. Roiter, 1996: International Satellite Cloud Climatology Project (ISCCP) documentation of new cloud datasets. WMO/TD-737, World Meteorological Organization, 115 pp., https://isccp.giss.nasa.gov/ pub/documents/d-doc.pdf.

Saunders, P. M., A. C. Coward, and B. A. de Cuevas, 1999: Circulation of the Pacific Ocean seen in a global ocean model: Ocean Circulation and Climate Advanced Modelling project (OCCAM). J. Geophys. Res., 104, 18281-18299, https://doi. org/10.1029/1999JC900091.

Schine, C. M. S., G. van Dijken, and K. R. Arrigo, 2016: Spatial analysis of trends in primary production and relationship with large-scale climate variability in the Ross Sea, Antarctica (1997-2013). J. Geophys. Res. Oceans, 121, 368-386, https:// doi.org/10.1002/2015JC011014.

Schmidtko, S., K. J. Heywood, A. F. Thompson, and S. Aoki, 2014: Multidecadal warming of Antarctic waters. Science, 346, 12271231, https://doi.org/10.1126/science.1256117.

Shchepetkin, A. F., and J. C. McWilliams, 2009: Correction and commentary for "Ocean forecasting in terrain-following coordinates: Formulation and skill assessment of the regional 
ocean modeling system" by Haidvogel et al., J. Comp. Phys. 227, pp. 3595-3634. J. Comput. Phys., 228, 8985-9000, https:// doi.org/10.1016/j.jcp.2009.09.002.

Shimada, K., S. Aoki, K. I. Ohshima, and S. R. Rintoul, 2012: Influence of Ross Sea Bottom Water changes on the warming and freshening of the Antarctic Bottom Water in the Australian-Antarctic Basin. Ocean Sci., 8, 419-432, https:// doi.org/10.5194/os-8-419-2012.

Smethie, W. M., and S. S. Jacobs, 2005: Circulation and melting under the Ross Ice Shelf: Estimates from evolving CFC, salinity and temperature fields in the Ross Sea. Deep-Sea Res. I, 52, 959-978, https://doi.org/10.1016/j.dsr.2004.11.016.

Smith, W. O., Jr., M. S. Dinniman, E. E. Hofmann, and J. M. Klinck, 2014: The effects of changing winds and temperatures on the oceanography of the Ross Sea in the 21st century. Geophys. Res. Lett., 41, 1624-1631, https://doi.org/10.1002/ 2014 GL059311.

Stammerjohn, S. E., D. G. Martinson, R. C. Smith, X. Yuan, and D. Rind, 2008: Trends in Antarctic annual sea ice retreat and advance and their relation to El Niño-Southern Oscillation and southern annular mode variability. J. Geophys. Res., 113, C03S90, https://doi.org/10.1029/2007JC004269.

— R. Massom, D. Rind, and D. Martinson, 2012: Regions of rapid sea ice change: An inter-hemispheric seasonal comparison. Geophys. Res. Lett., 39, L06501, https://doi.org/10.1029/ 2012 GL050874.

Steele, M., G. L. Mellor, and M. G. McPhee, 1989: Role of the molecular sublayer in the melting or freezing of sea ice. J. Phys. Oceanogr., 19, 139-147, https://doi.org/10.1175/ 1520-0485(1989)019<0139:ROTMSI >2.0.CO;2.

Stern, A. A., M. S. Dinniman, V. Zagorodnov, S. W. Tyler, and D. M. Holland, 2013: Intrusion of warm surface water beneath the McMurdo Ice Shelf, Antarctica. J. Geophys. Res. Oceans, 118, 7036-7048, https://doi.org/10.1002/2013JC008842.

Stewart, A. L., and A. F. Thompson, 2012: Sensitivity of the ocean's deep overturning circulation to easterly Antarctic winds. Geophys. Res. Lett., 39, L18604, https://doi.org/ 10.1029/2012GL053099.
- and - 2013: Connecting Antarctic cross-slope exchange with Southern Ocean overturning. J. Phys. Oceanogr., 43, 1453-1471, https://doi.org/10.1175/JPO-D-12-0205.1.

Timmermann, R., and H. H. Hellmer, 2013: Southern Ocean warming and increased ice shelf basal melting in the twentyfirst and twenty-second centuries based on coupled ice-ocean finite-element modelling. Ocean Dyn., 63, 1011-1026, https:// doi.org/10.1007/s10236-013-0642-0.

Trumbore, S. E., S. S. Jacobs, and W. M. Smethie, 1991: Chlorofluorocarbon evidence for rapid ventilation of the Ross Sea. Deep-Sea Res., 38, 845-870, https://doi.org/10.1016/ 0198-0149(91)90022-8.

Turner, J., and Coauthors, 2009: Non-annular atmospheric circulation change induced by stratospheric ozone depletion and its role in the recent increase of Antarctic sea ice extent. Geophys. Res. Lett., 36, L08502, https://doi.org/10.1029/2009GL037524.

_ J. S. Hosking, G. J. Marshall, T. Phillips, and T. J. Bracegirdle, 2016: Antarctic sea ice increase consistent with intrinsic variability of the Amundsen Sea Low. Climate Dyn., 46, 23912402, https://doi.org/10.1007/s00382-015-2708-9.

van Lipzig, N. P. M., J. C. King, T. A. Lachlan-Cope, and M. R. van den Broeke, 2004: Precipitation, sublimation, and snow drift in the Antarctic Peninsula region from a regional atmospheric model. J. Geophys. Res., 109, D24106, https://doi.org/10.1029/ 2004JD004701.

Whitworth, T., III, and A. H. Orsi, 2006: Antarctic Bottom Water production and export by tides in the Ross Sea. Geophys. Res. Lett., 33, L12609, https://doi.org/10.1029/2006GL026357.

S.-J. Kim, W. D. Nowlin Jr., and R. A. Locarnini, 1998: Water masses and mixing near the Antarctic Slope Front. Ocean, Ice, and Atmosphere: Interactions at the Antarctic Continental Margin, S. S. Jacobs and R. F. Weiss, Eds., AGU Antarctic Research Series, Vol. 75, Amer. Geophys. Union, 1-27

Willmott, C. J., 1981: On the validation of models. Phys. Geogr., 2, 184-194.

Zhang, J., 2014: Modeling the impact of wind intensification on Antarctic sea ice volume. J. Climate, 27, 202-214, https:// doi.org/10.1175/JCLI-D-12-00139.1. 